\title{
التمرد النفسي وعلاقته بأساليب المعاملة الوالدية لدى الأبناء$$
\text { من ذوي الإعاقة البصرية }
$$

\section{إعداد}

\section{هناء إبراهيم عبد الحميد}

مدرس علم نفس الطفل- كلية التربية للطفولة المبكرة- جامعة الإسكندرية

$$
\text { الإستشهاد المرجعى: }
$$

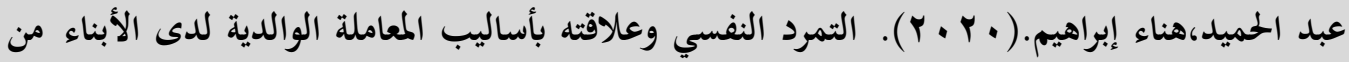
ذوي الإعاقة البصرية. مجلة بجوث ودراسات الطفولة. كلية التربية للطفولة المبكرة، جامعة بني سويف،

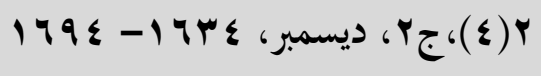




\section{5}

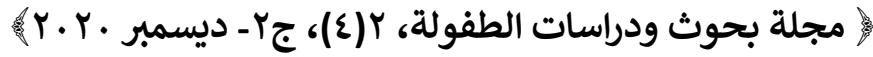




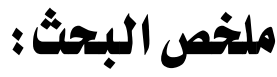

هدف البحث الحالى إلى معرفة ما إذا كان هنالك ارتفاع في حالات التمرد النفسي لدى الأبناء من ذوي الإعاقة البصرية ، ومعرفة ما إذا كان هناك علاقة ارتباطية بين التمرد النفسي وأساليب المعاملة الوالدية لدى الأبناء من ذوي الإعاقة البصرية.

كما هدف البحث الحالى التعرف على أهية متغير التمرد النفسي حيث أنه بعد الإطلاع

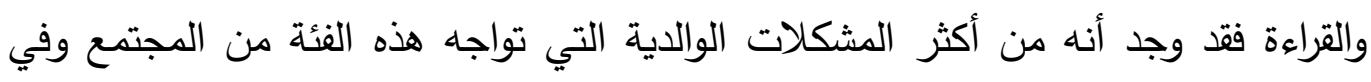

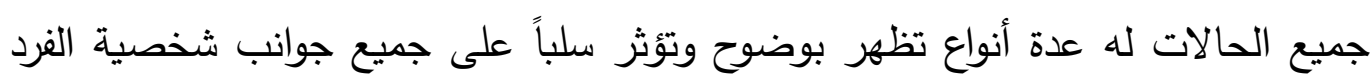

$$
\text { وهنا تكمن خطورته. }
$$

1- توجد علاقة دالة احصائياً بين درجات الأطفال المعاقين بصريا علي مقياس التمرد النفسي وأبعاد أساليب المعاملة الوالدية.

r- توجد فروق ذات دلالة إحصائية في فى مقياس التمرد النفسي والدرجة الكلية وفقاً

$$
\text { لبنوع (ذكور /اناث). }
$$

r- توجد فروق ذات دلالة إحصائية في فى أبعاد مقياس أساليب المعاملة الوالدية وفقاً

$$
\text { لـتغير النوع (أب/أم). }
$$

ع- يمكن التنبؤ بالتمرد النفسي من خلال أبعاد أساليب المعاملة الوالدية .

ه- يرتفع مستوي الرفض باعتبار أكثر أساليب المعاملة الوالدية استخداما مع الأطفال المعاقين

$$
\text { بصرياً. }
$$

الكلمات المفتاحية : التمرد النفسي، أساليب المعاملة الوالدية، ذوي الإعاقة البصرية 


\section{Abstract:}

The aim of the current research is to determine whether the amount of increase in cases of psychological rebellion in children with visual impairment, and to identify the significance correlation between psychological rebellion and parental treatment methods for children with visual impairment.

- The current research also aims to identify the importance of the psychological rebellion variable. As reviewing past researches and literature indicated that it is one of the most occurring parental problems facing this group of society and in all cases it has several types that appear clearly and negatively affect all aspects of the individual's personality and here lies its seriousness.

The results indicated that:

1- There is a statistically significant relationship between the scores of visually impaired children on psychological rebellion scale and the dimensions of parental treatment methods scale.

2- There are statistically significant differences on psychological rebellion scale and the total score according to gender (male / female).

3- There are statistically significant differences on the dimensions of parental treatment methods scale according to the type variable (father / mother).

4- The dimensions of parental treatment methods can predict Psychological rebellion.

5- The level of rejection increases as it is the most used parental treatment method for visually impaired children.

Keywords: Psychological rebellion -parental treatment methodsvisual impairment 


\section{كلية التربية للطفولة المبكرة- جامعة بني سويف}

\section{المقدمة}

يُعد الآباء هم حجر الأساس في تتشئة أبنائهم والعمل على تثكيل سلوكهم ومعاونتهم على النمو والتكيف مع أنماط الحياة المختلفة ولم يقتصر حول الآباء في تربية أبنائهم على المراحل الأولى فقط من عمرهم بل يمتد إلى مراحل الرشد والمراهقة.

وتُعد دراسة أساليب المعاملة الوالدية غاية في الأهمية لأن من خلالها سوف نتعرف

على سلوكيات هؤلاء الفئة من الأفراد حيث لها دور عظيم الأثر في تكوين شخصية أبنائهر. والذي يسعد أبناءنا من ذوي الاحتياجات الخاصة أن يشعروا بأن المجتمع من حولهم يحيطوهم بمقدار من الحب والأمان والاطمئنان وتكون معاملة المجتمع لهم معاملة طبيعية دون شعورهم بالتكلف والمغالاة حتى لا يشعرون بعجزهم فلابد أن تكون المعاملة سوية فلا يشعرون بالاهتمام الزائد أو بالنبذ والتجاهل الثديد.

وما يزيد الأمر صعوبة فقد نجد أن الوالدين والقائمين على تربية هؤلاء الأبناء قد

يتعاملوا مع أبنائهم بإهمال شديد وقد يكون ذلك نتيجة المفاهيم الخاصة في عقول الآباء أو بعضهم ومنها اعتبار الإعاقة نوعاً من العار الذي يجب أن يخفيه عن المجتمع وغيرها من

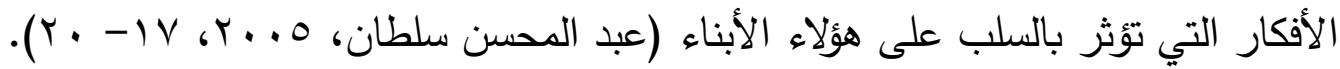

وتُعد الأساليب المستخدمة والتي يستخدمها الآباء مع أبنائهم ذوي الإعاقة البصرية

لها عظيم الأثر على شخصية وخصائص الأبناء، كما أن الأساليب المتطرفة التي تستخدم مع الطفل المبصر قد تؤثر أيضاً على شخصيته تأثيراً سلبياً فقد يكون النبذ أو الإهمال والرفض وعدم التقبل أو الحماية الزائدة للأبناء أو في تقديم الخدمات المطلوبة له بشكل زائد عن الحد مما يجعل الابن أكثر شعوراً تعجز عن مواجهة العديد من المشكلات والمواقف التي يمر بها وذلك يؤدي إلى شعور الطفل بعدم الثقة بالنفس وإنه دائماً بحاجة إلى الآباء فيشعر 
بالإحباط الثديد كذلك إتباع تلك الأساليب قد تؤثر على شخصية هؤلاء الاجتماعية فيفضل العزلة والانسحاب والانطوائية وبالعكس من ذلك فلو استخدم أساليب الرعاية الإيجابية كالتقبل

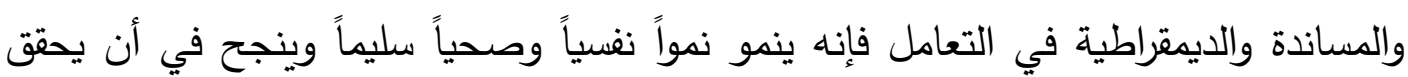
ذاته (عبد المطلب القريطي، 19991، 197 (- 90 (1).

وقد أكدت العديد من الدراسات منها دراسة علي محسن ومحمود كاظم (rا.ب)

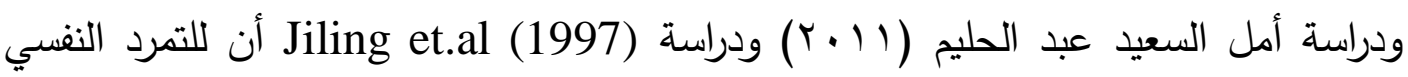
والعناد له علاقة ببعض المتغيرات السلوكية ويعد واحداً من الخصائص المميزة لسلوك الأبناء

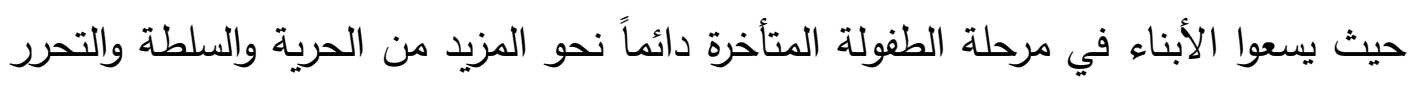
فيما يُعد من سلطة الوالدين حيث تتفاوت سلوكيات الأبناء تجاه المواقف والأثياء فهم من فن

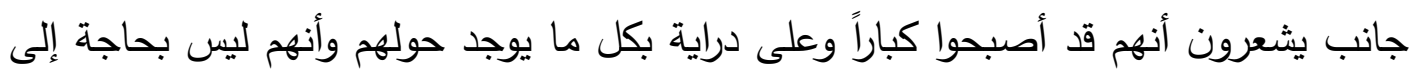
سلطة الوالدين ولكن من الجانب الآخر فهم يزالوا يعتمن على الجانب الاقتصادي للوالدين مما يؤدي إلى حدوث اختلافات في الآراء بين الآباء وأبنائهم وقد يختلف الوضع مع لهع الآباء إذا لها

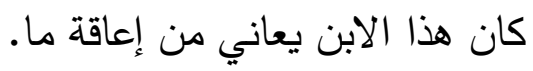

فقد ذكر محمد المهدي (ع ا ب أن أن الإعاقة البصرية تثكل أهمية للفرد في الممارسات اليومية وتكوين التصورات الذهنية والتعرف على مكونات البيئة من حوله كما أن هذه الإعاقة تؤثر تأثيراً كبيراً على مظاهر النمو الاجتماعي والنفسي مما يترتب عليه ظهور مشكلات

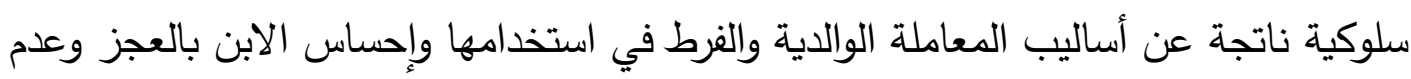
القدرة على إتمام مهامه بمفرده. فقد اهتم علماء النفس وعلماء التربية الخاصة بأساليب المعاملة الوالدية بدرجة كبيرة لما لها الأثر البالغ في عمليات التنشئة الأسرية. 


\section{كلية التربية للطفولة المبكرة- جامعة بني سويف}

وقد أكد ياسره أبو هدروس (•l+r) أن الأبناء في مرحلة الطفولة المتأخرة يمرون بالعديد من المراحل وأن التغيرات التي تحدث في النمو الجسمي والعقلي والفسيولوجي وأيضاً في النواحي الخلقية والاجتماعية فقد يحدث العديد من الصراعات التي تتعرض لها الأبناء سواء كان هذا التغير قد يؤثر داخلياً أو خارجياً، فلابد أن يتكيف الطفل مع عالمه الجديد فكل مرحلة من هذه المراحل التي يمر بها ينتابها شيء من الصعوبة كالصراعات النفسية والضغوط الاجتماعية وغيرها مما تجعل هؤلاء الأبناء يتجهوا إلى التمرد النفسي. وتُعد مظاهر التمرد النفسي التي تنشأ عند الأبناء في مرحلة الطفولة المتأخرة من

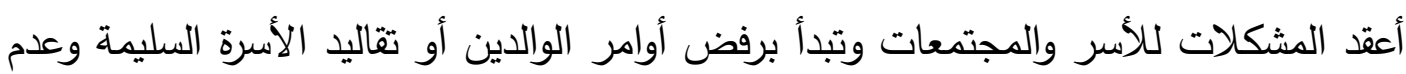

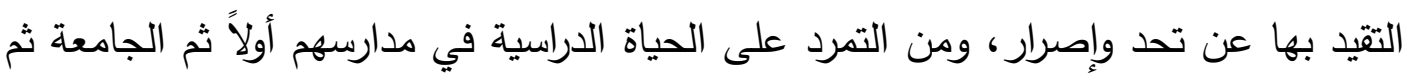
يأتي دور التمرد على القانون والمجتمع والسلطة. وإن الظواهر والمشكلات السلوكية التي تظهر عند بعض الأبناء تعد انحرافاً عن أهداف السياسة التعليمية لذا كان على المهتمين بالتربية والتعليم أن ينتبهوا لتلك المشكلات وأن يدرسوا أسبابها وطرق علاجها حتى تصبح مخرجات التعليم متوافقة مع أهدافها المحددة

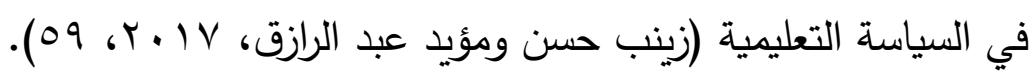

كما أن ظاهرة التمرد النفسي لم تلق إلا القليل من الاهتمام من قبل الباحثين والمنظرين والمحدثن ويُعد دونيل وآخرون Donnel, Tomas, Buboltz \& Walter (2001) من أشهر المنظرين في هذا الهجال، حيث يرى أن نظرية "التمرد النفسي" تقيد بأن الأشخاص يقاومون محاولات تقييد أي من تفكيرهم أو تصرفاتهم، وأن كل فرد لايه اعتقاد بأنه يمتلك قدراً من الحرية المعرفية والسلوكية وأن هذه الحرية إذا هددت فإنهم سيسلكون سلوكاً تمردياً ومقاوماً وذلك في محاولة منهم لاستعادة حريتهم الsفقودة. 


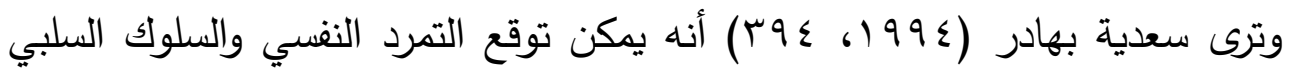

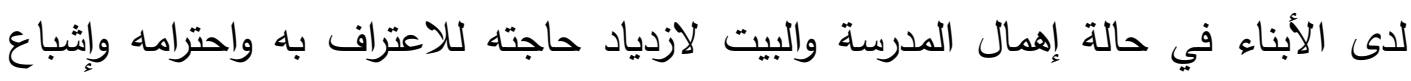

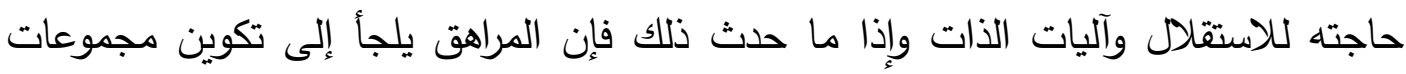
خاصة به من الأصدقاء ويحاول أن يخفي تصرفاته عن والديه، بل قد يعود صدهم ويحاول

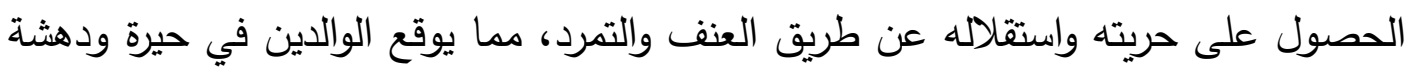
لاعتقادهم بأن المراهق غير معد لتوفير تلك الحرية له وترى الباحثة أن أساليب المعاملة

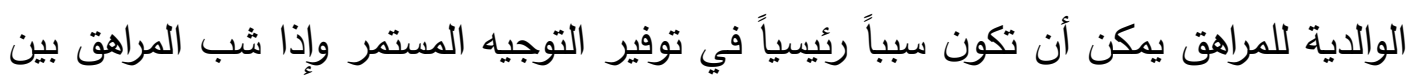
والدين صارمين متثددين متسلطين لا ينتجان له الفرصة لتأكيد ذاته في الحقوق فإنه يتجه

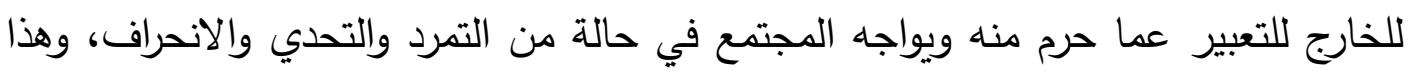
ما أكده ماريو Mario (2007, 635-647 حيث يرى أن العلاقات الوالدية الحسنة وذات الكفاءة العالية مع الأبناء فى مرحلة الطفولة المتأخرة تقلل من مستويات العنف والتمرد

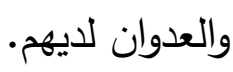

وبالرغم من ذلك التأثير الفعال من قبل المعاملة الوالدية للأبناء إلا أن الإعاقة

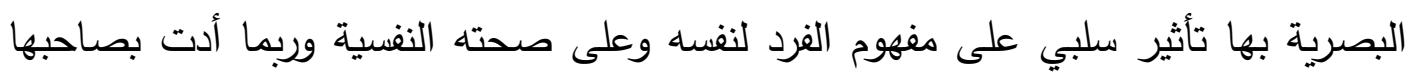
على عدم القدرة على التكيف في المجتمع الذي يعيش فيه بجانب حدوث اضطرابات نفسية

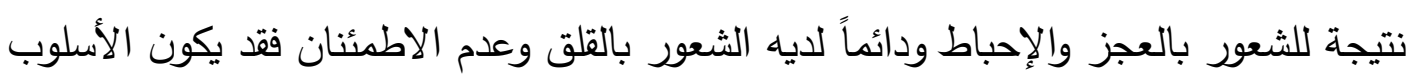
الوالدي الدتعامل به كالإثفاق والتدليل والحماية الزائدة أو الإهمال والتجاهل أي كان واندان أحداهم قد يساهم في الثعور بالعجز والقصور وأنه يختلف على الآخر .

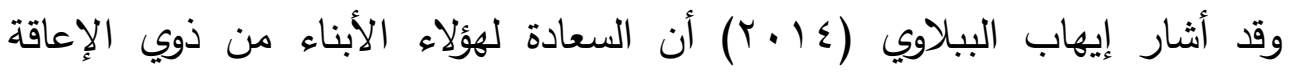
البصرية وإزالة المعوقات التي تحد من نموه وإعادته إلى مجتمعه من خلال تكيفه النفسي

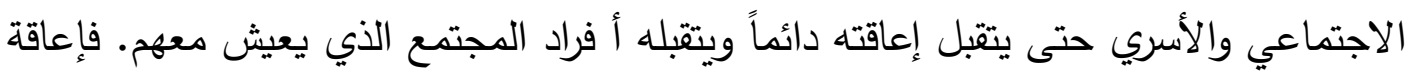




\section{كلية التربية للطفولة المبكرة- جامعة بني سويف}

الفرد هي إعاقة لأسرته فقد يحدث اختلاف للأسرة والثعور بالذنب تجاه ابنهم المعاق وتأكيداً على القول السابق أن هناك العديد من الدراسات التي أكدت على أن الأبناء ذوي الاحتياجات الخاصة يتعرضون لأساليب معاملة والدية غير سوية .

\section{مشكلة البحث}

تُعد مشكلة التمرد النفسي واحدة من المشكلات التي يعاني منها الآباء في تصرفات أبنائهم ومن خلال الإطلاع والقراءة ومقابلة أولياء الأمور والتعرف على الأساليب التي يتعود بها في تتشئة أبنائهم الأسرية ومن خلال مقابلة هؤلاء الأبناء فقد لاحظت الباحثة أن المعاملة الوالدية تعد من أهم الدحددات التي تساعد على تتمية المرونة والسواء النفسي العام لهؤلاء الأبناء.

وقد أشارت عديد من الدراسات إلى تأثير أنماط التتشئة الوالدية على الأبناء سواء من

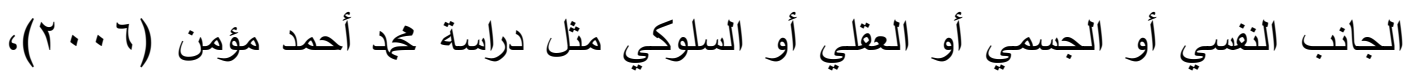

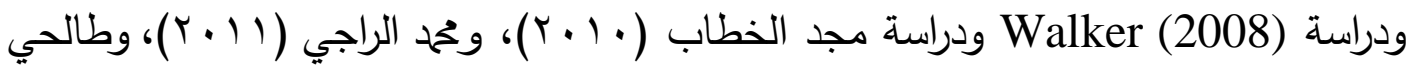

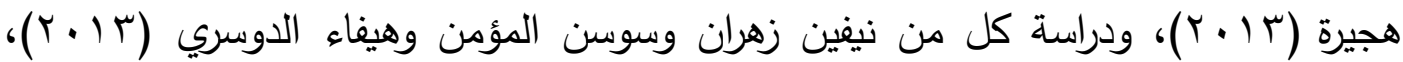
ودراسة مروة بنت ناصر (T/. (Y)، حيث ذكروا أن استخدام أحد من الأنماط فقد يؤثر بالإيجاب أو السلب على الأبناء. ولذلك فقد صيغت المشكلة من خلال التساؤلات الآتي: 1- ما علاقة التمرد النفسي بأساليب المعاملة الوالدية لاى الأبناء من ذوي الإعاقة

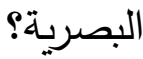

r- هل توجد فروق ذات دلالة احصائية فى التمرد النفسي وفقاً للنوع (ذكور/اناث)؟ r- هل توجد فروق فى استخدام أساليب المعاملة الوالدية وفقا لنوع الوالد (أب/أم)

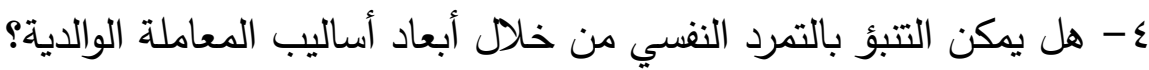


0- ما أكثر أساليب المعاملة الوالدية شيوعا لدي أباء المعاقين بصريا؟

\section{أهداف البجث}

• تهدف هذه الدراسة إلى معرفة ما إذا كان هناك ارتفاع في حالات التمرد النفسي لدى الأبناء من ذوي الإعاقة البصرية.

• تهدف هذه الدراسة لمعرفة ما إذا كان هناك علاقة ارتباطية بين التمرد النفسي وأساليب المعاملة الوالدية لدى الأبناء من ذوي الإعاقة البصرية.

\section{أهمية البحث}

ظهرت أهمية البحث متمثلة في المتغيرات التي تناولها وهي على النحو التالي: • أهمية الفئة التي تتناولها البحث وهي فئة لدى الأبناء من ذوي الإعاقة البصرية وأهمية هذه المرحلة وخطورتها إذا لم يتبع معها أسلوب المعاملة الوالدية السوي.

• أهمية متغير التمرد النفسي حيث أنه بعد الإطلاع والقراءة فقد وجد أنه من أكثر المشكلات الوالدية التي تواجه هذه الفئة من المجتمع وفي جميع الحالات له عدة أنواع تظهر بوضوح وتؤثر سلباً على جميع جوانب شخصية الفرد وهنا تكمن خطورته. • أهية متغير الأساليب الوالدية الذي يحتل مكانة خاصة في الدراسات النفسية حيث أنه يحفز الأفراد للتحسين.

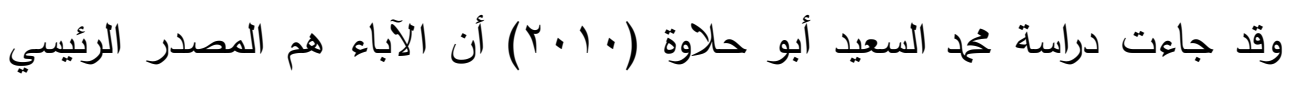
لتزويد الأطفال بما يضح تسميته لخريطة طريقة الإبحار الإيجابي في الحياة وهم كذلك المصدر الرئيسي لتنمية قدرات أبنائهم على التأقلم والتكيف الإيجابي والتغلب على الصعاب. 
كما أن هؤلاء الآباء لهم دور في تعليم أبنائهم المهارات والاتجاهات التي تمكنهم من

$$
\text { التوافق الذاتي والاجتماعي في الحياة. }
$$

• ظهور هذه المشكلات السلوكية التي تعترض شخصية هؤلاء الفئة. • كما ظهرت أهمية البحث الحالي في ضوء ندرة الدراسات التي تتاولت التمرد النفسي وعلاقته بأساليب المعاملة الوالدية وخاصة الأبناء من ذوي الإعاقة البصرية. وهذا ما شجع الباحثة على اختيار هذه المتغيرات لدراستها إجراء البحث الحالي.

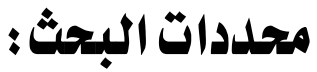

أولاً: المـنهج: تعتمد الدراسـة الحالية على المنهج الوصفى الارتباطى وذلك بهدف الكشف العلاقة بين التمرد النفسي وأساليب المعاملة الوالدية ومقارنتها لدي الذكور والاناث والأمهات والأباء وكذا التعرف علي أساليب المعاملة الوالدية المنبأة بالتمرد النفسي ثانياً :عينة البحث

تكونت عينة البحث الأساسية من ( آ) من المعاقين بصرياً من الذكور والاناث ممن تراوحت

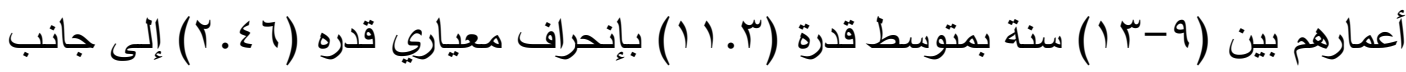
عينة من الأباء والأمهات - أدوات البحث: - n - n 1- مقياس أساليب المعاملة الوالدية لآباء الأبناء من ذوي الإعاقة البصرية. r- مقياس التمرد النفسي للأبناء من ذوي الإعاقة البصرية.

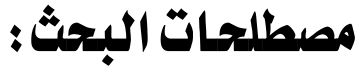

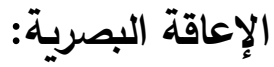

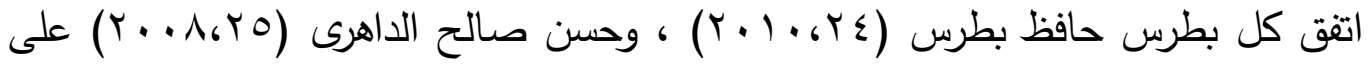
أن الانسان المكفوف هو الذى فقد بصره بالكامل ولا يستطيع تعلم القراءة والكتابة إلا بطرق 
برايل ، وهناك درجات متفاوتة من الفقدان البصري يتراوح بين حالات العمى الكمي بين لا يملكون الإحساس بالضوء ولا يرون شيئاً على الإطلاق ويتعين عليهم الاعتماد الكلي على حواسهم الأخرى تماماً على حياتهم اليومية وتعلمه وحالات الإعاقة أو للإبصار الجزئي التي تتفاوت مقدرات أصحابها على التمييز البصري للأشياء المرئية، ويمكنهم الإفادة من بقايا بصرهم مهما كانت درجاتها في التوجه والحركة وعمليات التعلم المدرسي سواء باستخدام المعينات البصرية أو دونها. التعريف الإجرائي:

هم هؤلاء الأطفال من ذوى الإعاقة البصرية الكلية فى مرحلة الطفولة المتأخرة حيث يفقدون المقدرة على استخدام حاسة البصر بفاعلية بما يؤثر سلباً في أدائهم ونموهم. أساليب المعاملة الوالدية: هو واحد من العناصر الأساسية في عملية التنشئة الاجتماعية وفيها يتم تتمية أنماط توعية من الخبرات والسلوكيات الاجتماعية الملائمة من خلال التفاعل مع الآخرين، فهي تعد التفاعل بين الوالدين والأبناء في مراحل العمر المختلفة وارتباطها تحسن توافقه (علاء الدين

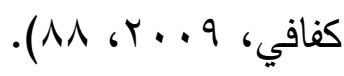

$$
\begin{aligned}
& \text { التعريف الإجرائي: }
\end{aligned}
$$

هي الأساليب التي يتبعها الوالدين في تتشئة أبنائهر من ذوي الإعاقة البصرية اجتماعياً ونفنياً وتحويلهم من مجرد كائنات بيولوجية إلى كائنات اجتماعية. التمرد النفسي: يعرفه (687 -679) بأنه مجموعة من السلوكيات التي يمارسها الفرد عندما تقيد حريته في التفكير والتصرف وذلك لمحاولة استعادة حريته المفقودة. 


\section{كلية التربية للطفولة المبكرة- جامعة بني سويف}

التعريف الإجرائي:

هو عبارة عن قوة عقلية تنتج نتيجة شعور الطفل ذوي الإعاقة البصرية بالنقص في ممارسة حريته الثخصية فيلجأ إلى التمرد النفسى لإثبات نفسه والتأثير في الآخرين.

الإعاقة البصرية:

لم تكن ظاهرة الإعاقة البصرية وليدة الوقت الحاضر وإنما هي مشكلة منذ قديم

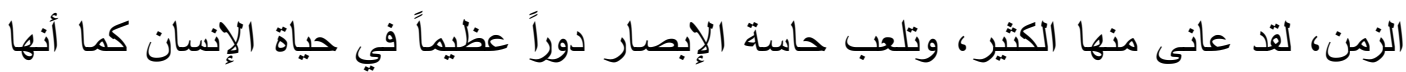
لها تأثير كبير دون غيرها على الجوانب الاجتماعية والبيئة مما يؤثر تأثيراً سلبياً على أصحابها من حيث التفاعل بينه وبين بيئته التي يعيش فيها.

فإن حاسة البصر من أهم حواس الإنسان على الإطلاق حيث أن فقدانها يفقد الطفل خبراته اليومية التي تتكون من الألوان والأكال ويصعب عليه تكوين الصورة الذهنية عن معظم الأشياء الموجودة حوله بعكس باقي زملائه المتضررين، فالطفل في هذه المشكلة يحاول أن يعوض حاسة البصر بحاستي السمع واللمس ولكنها لا تكفي ولا تكون بديلاً من حاسة

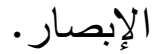

\section{تعريف الإعاقة البصرية:}

لقد عرفها كمال سيسالم (ץ ...r، 0. ؟) أنها الفقدان الكلي أو الجزئي للبصر ويعتبر

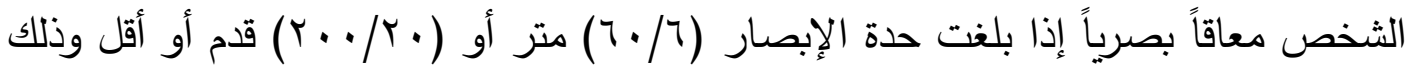
باستخدام النظارات أو العدسات المصمدة كما ويعتبر الثخص معاقاً بصرياً إذا كان مجال

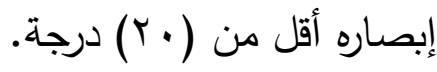

كما اتقق كل من زينب شقير (1999، سTr)، عبد المطلب القريطي (7999)، (IVV على أن الكفيف أو الأعمى هو الفرد الذي لا يستطيع أن يقوم بالأعمال اليومية 
الحياتية إذا قل نظره عن (؟// ^) متر في أحد العينين وذلك بعد تحسينها باستخدام النظارات الطبية أو العدسات.

وقد أشار محمد عصام طربية (• ( • ( إلى أن تاريخ ذوي الاحتياجات الخاصة إلى أن الأفراد ذوو الإعاقة البصرية لم يكونوا أسعد حالاً من الأفراد ذوي الإعاقات الأخرى، فقد كان يعامل المكفوفين في العهود السابقة معاملة سيئة من قبل المجتمع، حيث لا يجدون الرعاية والعناية ويهملون، وفي أحسن الحالات كان ينظر إليهم باعتبارهم من ذوي العاهات الذين يثيرون الثفقة حيناً والازدراء حيناً آخر، أما في أسوأ الحالات فقد كان يتم تعريض الأطفال المكفوفين للموت للتخلص منهم.

لم يتوفر تعريف جامع للإعاقة البصرية، على الرغم من أنه مصطلح سهل ومتداول بين الناس، ويرجع ذلك إلى أن الإعاقة البصرية ليست مصطلحاً لغوياً قاموسياً يسهل تفسيره برح المدلولات اللغوية المتصلة به بل هو مصطلح شامل يذهب في اتجاهات تخصصية مختلفة. فقد عرفت الإعاقة البصرية على أنها فقدان البصر وأخرى على أنها عدم قدرة العين على رؤية الأشياء أو الأجسام بشكل واضح أو كما هو معتاد ومن تلك التعريفات ما يلي:

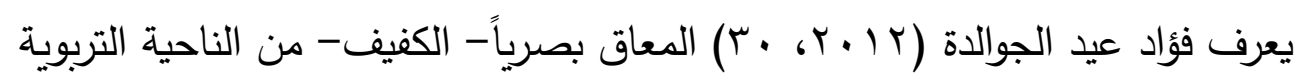
بأنه: الثخص الذي لا يستطيع أن يقرأ أو يكتب إلا بطريقة برايل.

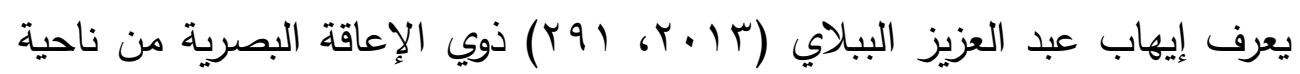
تربوية بأنهم: الأشخاص الذين يحتاجون خدمات التربية الخاصة بسبب مشاكلهم البصرية الأمر الذي يستدعي إحداث تعديلات خاصة على أساليب التدريس والمنهاج ليتمكنوا من النجاح تربوياً: 


\section{كلية التربية للطفولة المبكرة- جامعة بني سويف}

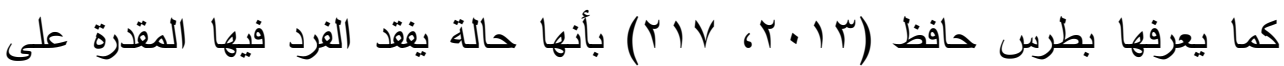
استخدام حاسة البصر بفاعلية مما يؤثر سلباً في أدائه ونموه.

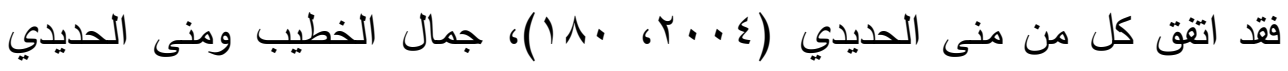

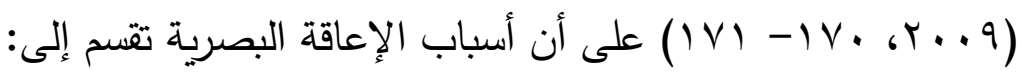

\section{أسباب الإعاقة البصريةة:}

فقد تعددت أسباب الإصابة بالإعاقة البصرية:

1- فهناك أسباب ما قبل الولادة وتثتمل العوامل الوراثية والبيئية وهي إصابة الأم الحامل ببعض الأمراض.

ץ- هنالك أسباب أثناء الولادة نفسها، العوامل الوراثية فكثير ما تظهر تأثيرها منذ الولادة. r- أسباب ما بعد الولادة: وتعرف بالعوامل الغير وراثية المسببة للإعاقة البصرية بالعوامل المكتسب به وتثمل زيادة نسبة (الأكسجين، الخدج، الأمراض التي تصيب العين والإصابات الناجمة عن الحوادث) مثل:

r) (بتلال الشبكة الناتج عن السكري.

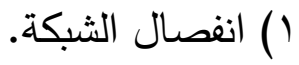

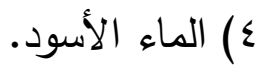
r) (بتكاس النقطة المركزية.

7) التليف خلف العدسة.

^) القصور في الأنسجة.

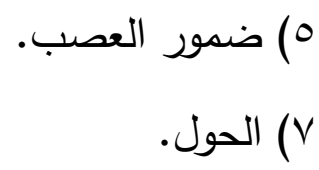

9) رأرأة العين.

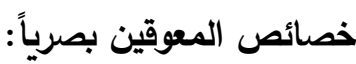

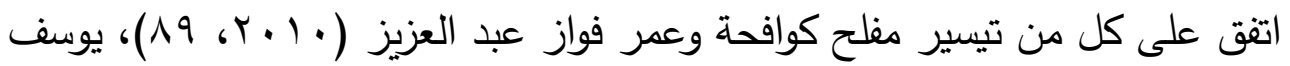

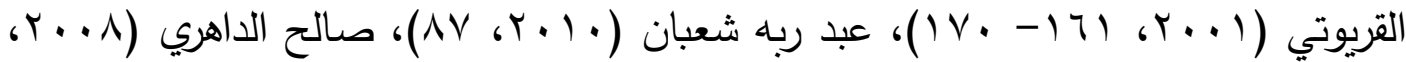


حيث يتصف المعوقين بصرياً بخصائص معينة تمزيهم عن المبصرين وتشمل:

\section{[1] [الخصائص الجسمية:}

قد نجد أن للإعاقة البصرية لها آثار جسمية مختلفة على العاديين ولكن النمو الجسمي كالطول والوزن قد يتقق مع العاديين ولا يختلف عنهم في شيء ولكن قد نجد أن هناك قصور في بعض المهارات الحركية فهم لديهم قصور في مهارات التتاسق العضلي والحركي وذلك ناتج عن إعاقتهم المصرية فهم يفقدوا فرص التقليد للكثير من المهارات الحركية.

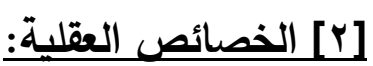

ومن الجانب العقلي فقد نجد صعوبة في قياس نسبة الذكاء لدى الأبناء المكفوفين وضعاف البصر وذلك لأن معظم اختبارات الذكاء تشتمل على أجزاء لابد أن يؤديها الكفيف مثل بناء مكعبات أو تجميع الأشكال وبالتأكيد فإن تلك الألعاب غير مناسبة للاستخدام مع تلك الفئة من الأبناء فقد يلجأ العديد من الباحثين في الاعتماد على الجزء اللفظي من المقاييس، كما أن هؤلاء الفئة يواجهون مشكلة في مجال إدراك المفاهيم وتكوين الصور للأشياء ولكنهم يتميزون في الانتباه والذاكرة السمعية فقد يتفوقون فيها على أقرانهم المبصرين فإنهم يعتمدوا بالدرجة الأولى على حاسة السمع.

\section{[ب] الخصائص اللغويـة:}

لا يعتبر ضعف حاسة البصر أو فقدانها من العوامل المعيقة لتعلم الطفل اللغة وفهح الكلام، إلا أن لها أثراً على بعض مهارات الاتصال اللفظي الثانوي، وعلى سبيل المثال فإن الحرمان من حاسة البصر لا يسمح للمعوق بصرياً تعلم الإيماءات والتعبيرات ومن أهم أنواع اضطرابات اللغة والكلام التي يعانيها بعض المعاقين بصرياً ما يلي: ا - العلو: يتمثل في ارتفاع الصوت.

ץ- عدم التغير في طبقة الصوت بحيث يسير الكلام على نبرة واحدة. 


\section{كلية التربية للطفولة المبكرة- جامعة بني سويف}

\section{r- قصور في الاتصال بالعين مع المتحدث.}

ع - القصور في استخدام الإيماءات والتعبيرات الوجهية والجسمية المصاحبة للكلام. 0-اللفظية وهي الإفراط في الألفاظ على حساب المعنى.

\section{[؛] [الخصائص الاجتماعية:}

قد تتأثر النواحي الاجتماعية عند الكفيف من زاويتين الأولى وهي من ناحية التفاعل الاجتماعية والثانية من ناحية درجة تقبل المجتمع للفرد المعاق بصرياً ومدى تكيف مع المجتمع الذي يعيش فيه، ولكن من خلال تدريهم فقد يزيد فرص التفاعل الاجتماعي لديهم، وقد أثبتت العديد من الدراسات أن المعوقين بصرياً الذين يتلقونه خدمات تربوية في المدارس العادية قد يكونوا أكثر توافقاً ممن في مدارس التربية الخاصة أو المدارس الداخلية. فمن خلال تدريبهم على المهارات الحياتية كالعناية بالذات والتنقل في البيئة المحيطة بهم مما يعمل على جعل المعوق بصرياً أكثر ثقة بنفسه وأكثر اعتماداً على نفسه مما يسهم بشكل كبير على تحسين اتجاهاتهم.

\section{[0] [الخصائص الأكاديمية:}

لا يوجد اختلاف بوجه عام بين ذوي الإعاقة البصرية والمبصرين خاصةً فيما يتعلق بالقدرة على التعلم حيث يتم الاستفادة من المنهج التعليمي ولكن يتطلب أن يوجد تعديل في الأسلوب المقدم للهمم حتى يتلاءم مع ظروفهم الخاصة.

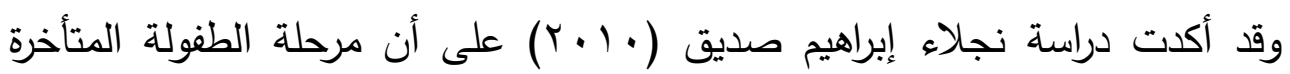
مرحلة هامة في حياة الفرد لها خصائص معينة تميزها عن غيرها من المراحل التي تسبقها والتي تليها وتعتبر كل مراحل حياة الفرد هامة بالنسبة إلا أن بعضها أكثر أهمية من الأخرى وذلك إما بسبب تأثيراتها الحالية على الاتجاهات والسلوك أو بسبب تأثيراتها طويلة المدى في حياة الفرد ولكن المراهقة تجميع بين الأهميتين حيث أن لها تأثيراتها حالية وطويلة المدى 
فنجد أن الإعاقة البصرية لها تأثيرها على المراهقة حيث تحرمه من إثباعهم لحاجاتهم بطريقة مناسبة وتولد لديهم شعوراً بالنقص وتؤثر عليهم سلباً ويحصل تدني في تقديرهم لذاتهم فيبدأ الطفل المعاق بصرياً في التخلص من الأنانية وينمو الإحساس بالرابطة والولاء نحو الجماعة ويصل هذا الولاء في كثير من الأحيان إلى تعصب أعمى وكذلك يتصف بالخجل نتيجة للتغيرات العضوية المفاجئة ويميل إلى التردد نتيجة لعدم الثقة في نفسه لعدم فهم طبيعة التغيرات ومداها كذلك ينزع إلى التذمر والانسحاب من سلطة الأبوين إلى سلطة الجماعة ويميل إلى التحرر من السلطة ويثور عليها أحياناً ويميل المراهق إلى اختيار أصدقائه بنفسه لا أن تفرض عليه الأسرة أصدقاء، وتبدو انفعالاتهم عنيفة ويثور لأتفه الأسباب ويتميز النمو الوجداني بحب الزعماء والعظماء ويتخذ منهم مثله العليا وكذلك نجد أن بعض الأطفال فى مرحلة الطفولة المتأخرة يتميزون باليأس والحزن والآلام النفسية بسبب تقاليد المجتمع التي تحول بينهم وبين تحقيق رغباتهم وتكون بعض العواطف الثخصية نتيجة نمو الذات ونتيجة عواطفه نحو الأشياء والمعاني الجميلة التي تتميز بالرومانسية. والفرد المعاق بصرياً مثله مثل الأفراد العاديين يمرون بمراحل النمو العادية ويصل إلى مرحلة المراهقة ومن هنا يحاول الأبناء فر سيطرتهم على أبنائهم أو يظل تحدت طوع آبائهم على حسب أساليب المعاملة الوالدية التي كان يتعامل بها ومرحلة المراهقة تعد من أهم المراحل في حياة الأبناء فهي فترة معينة يترتب عليها سلوكيات جديدة لم يتعرف عليها الفرد من قبل. فقد جاءت دراسة أزهار ححم مجيد (1) (1) حيث عرفت الأبناء المتمردين بأنهم الطلاب الذين تبدأ أن تتكون شخصيتة ويبدأ أن يتمرد على الأساليب المتبعة معه نتيجة

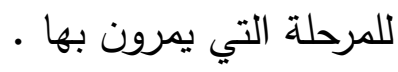




\section{كلية التربية للطفولة المبكرة- جامعة بني سويف}

التمرد النفسي:

يعد التمرد النفسي من المواضيع التي اهتم بدراستها علم النفس باعتبارها متغيراً مهماً يرتبط ارتباطاً مباشراً بسلوك الإنسان ومع دخول التمرد لتفسير مظاهر التغير الاجتماعي ليشمل كل ما يقوم به الفرد من سلوك لإشباع حاجاته ورغباته، فتحقق هدفه في الحياة. وذكرت خلود بثير (9 . r) أن التمرد يعني الرفض الذي يظهره الفرد لكل ما هو قائم ومبادئ وعادات وتقاليد ومقاومة السلطة برموزها المختلفة (الوالدية، والتعليمية وأي سلطة في المجتمع)، والميل إلى انتقادها وتحديها وللتمرد صور وأشكال مختلفة قد يكون (مباشراً) صريحاً، كالتمرد على الأسرة وقيمها وأخلاقياتها أو عقيدتها والمهن التي ترضيها كما يبدو في شكل مخالفات في الملبس أو تمضية أوقات الفراغ أو يكون (غير مباشر) كالإذعان لمطالب السلطة، ولكن في الوقت نفسه يحاول إظهار تمرده عن طريق تحريض الآخرين على عدم

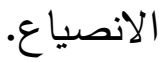

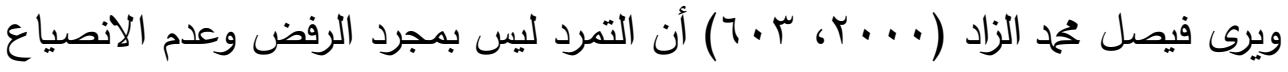
لما ألفه الأفراد فهناك من المألوفات أو القوانين والعقائد والقوى غير الصحيحة ما يجب رفضه والتمرد عليه، والتمرد الذي يظهر في حياة الثباب المنطلق من الثعور بالقوة والتحدي وضرورة التغيير يتجه اتجاهين متناقضين اتجاهاً سلبياً ضاراً وهداماً واتجاهاً إيجابياً مغايراً يساهم في تطور المجتمع والدفاع عن مصالحه، فظاهرة التمرد السلبي أو التمرد على ما ينبغي الالتزام به من عقيدة سليمة وقيم له أسبابه الذاتية و الموضوعية التي ينبغي دراستها للتعامل معها بوعي وتخطيط. تعريف التمرد النفسي:

قد عرف Mcdarmoth \& Baink (2014) التمرد بأنه واحد من أشكال الأفعال التي تحقق الرغبة في الحرية والتخلص من القيود وفق بعدين هما الأول السلوك المتمثل بردود أفعال لا مسئولة، وانتقامية وعدوانية وتكون ناتجة عن استجابات لتهديد أو فرض القيود 
والتي من خلال شعر الفرد بخيبة الأمل والإحباط الثديد والثاني عبارة عن أفعال ناتجة عن الشعور القهري أو الرغبة في مخالفة ما هو موجود في المجتمع فقد عرفته ياسرة أبو هدرس التهل

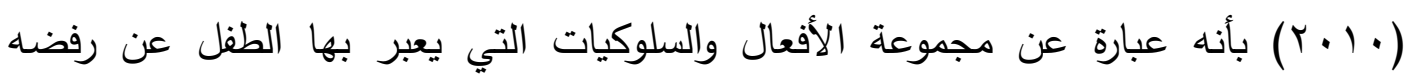
لمحاولات تتييد حريته الفكرية والسلوكية والتي تقع ضمن ثلاثة أبعاد وهي: بانه

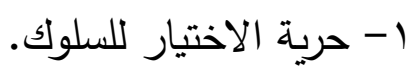

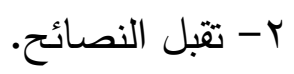

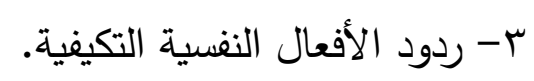

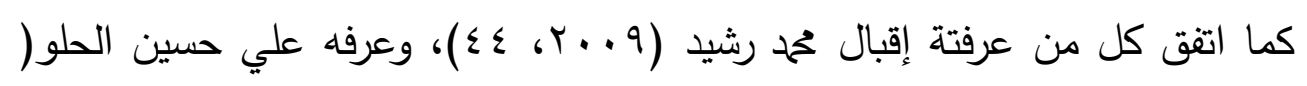

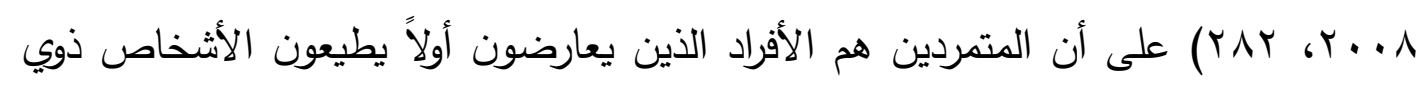

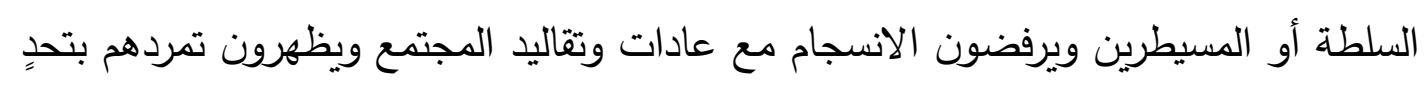

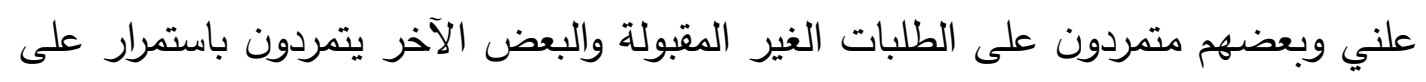
جميع القوانين.

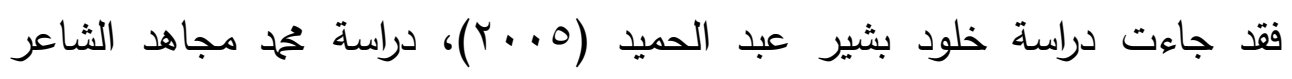

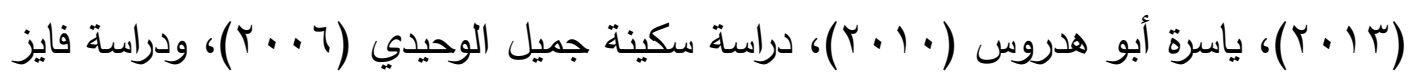

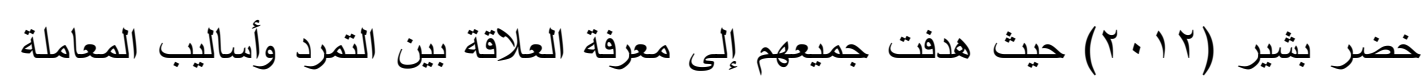
الوالدية والضغوط النفسية لاى هؤلاء الأبناء، وتوصلت الدراسات إلى وجود فروق ذات دلثات دلالة

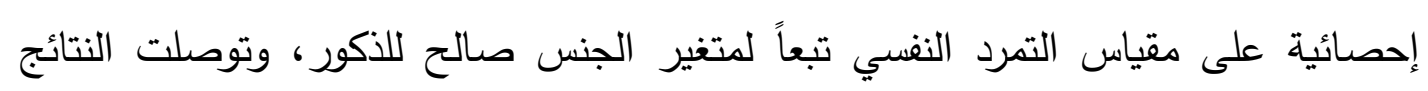

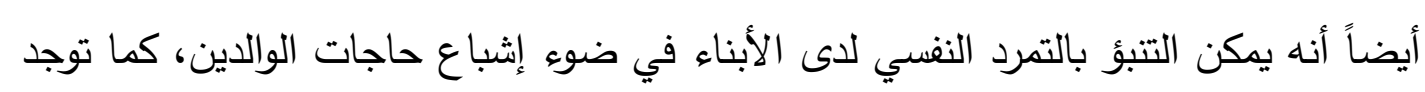
علاقة بين متوسط التمرد النفسي ومتوسط إثباع الحاجات النفسية لاى أبنائهر. 


\section{كلية التربية للطفولة المبكرة- جامعة بني سويف}

فقد يسعى الأبناء دائماً سواء كان من العاديين أو من ذوي الإعاقة البصرية نحو

$$
\text { التمرد والبحث عن الحرية والبعد عن تسلط الوالدين. }
$$

وقد أشارت العديد من الدراسات إلى خصائص الأفراد المتمردين نفياً ومنهم Johnson, دراسة، دoubchoff (1997) Bubolls \& walter (2000) ودراسة Hellman \& McMillin (1997)، حيث أنهج يتسمون بمستويات عالية من أعراض الصرامة والقسوة وبمقاومة شديدة جداً لإتباع توجيهات وإرشادات المرشد النفسي، ومن ناحية أخرى أن التمرد النفسي يرتبط ارتباطاً سلبياً بتقدير الذات للسعادة، في حين يرتبط ارتباطاً إيجابياً بالوحدة النفسية، كما أثارت نتائج دراسات إلى أن هناك ثلاثة مقاييس نفسية يمكنها التتبؤ بالمستوى النفسي لدى الأفراد وهي: مقياس التمايز بين الأجيال، ومقياس معاشرة الأقران، ومقياس التمايز بين الأقران، كما أشارت نتائج الدراسات إلى أن التمرد النفسي والنفسي يرتبط ببعض الخصائص الشخصية مثل: تقدير الذات، وسمة الغضب ومركز التحكم والضبط والاكتئاب، ودراسة سنج وآخرين، كما اهتم أيضاً بأثر كل من الجنس والعمر في مستوى التمرد النفسي، حيث أشارت نتائج الدراسات إلى أن أسلوب الإجبار والإكراه الذي يفرض على الأفراد ربما يسهل إحداث تغييرات في مستويات التمرد النفسي، حيث أن السلطة الأبوية وأسلوب الإجبار يزيد من مستويات التمرد النفسي لاى الأفراد الأصغر سناً.

ويمكن حصر بعض السمات الشخصية المتمردة في النقاط الآتية:

1- الشعور دائماً بقلة الرضا مع عائلاتهم.

r- لديهم القدرة على الإسراف والإنفاق والتأخر الدراسي.

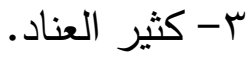
ع - كثير العدوان على الأصدقاء والأخوات.

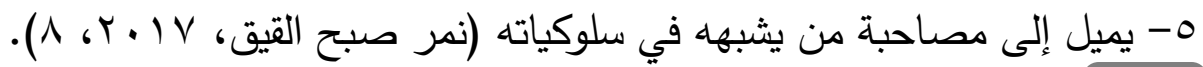


قد اتفق كل منهم على أسباب التمرد النفسي.

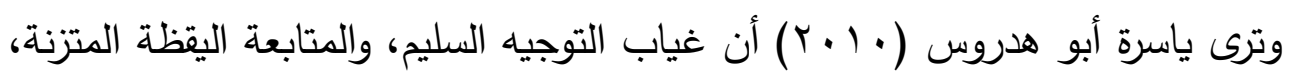

والقدوة الصحيحة يقودان المراهق نحو التمرد، كما أن ضعف الاهتمام الأسري بمواهب المراهق وعدم توجيهها الوجهة الصحيحة، وتأنيب الوالدين لله أمام أصدقائه، ومتابعته للأفلام والبرامج التي تدعو للتمرد على القيم الدينية والاجتماعية والعنف، يعد من العوامل المهمة في حدوث ظاهرة التمرد النفسي، ولعل افتقار الأدب السيكولوجي العربي إلى دراسات حول "التمرد النفي" لاى الأبناء فى مرحلة الطفولة المتأخرة يعد سبباً مباشراً دفع الباحثة إلى إجراء هذه الدراسة .

أسباب التمرد النفسي:

قد ذكر كل من خولة محه زايد (990 ())، ابتسام العيبس (1 (...)، إقبال محه رشيد

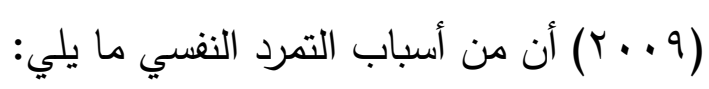
1- الحرمان الأسري المتمثل بفقدان أحد الوالدين أو كليهما (خولة محمد مطارنة، 990 (، ^). ץ- أساليب المعاملة الوالدية والتنشئة الاجتماعية التي تؤكد على إنماء الذاتية الفردية كونها نوعاً من الرجولة المطلوبة على حساب القيم الوطنية الأخلاقية. ب- أساليب التتشئة الاجتماعية التي أصبحت أقل فاعلية في عهد التغيير الاجتماعي السريع مما أدى بالنتيجة إلى تزايد الفجوات في المعايير الأساسية بين الثباب والكبار (ابتسام

$$
\text { العيبس علي اللامي، ( (. ب.، م). }
$$

ع - طريق لإثبات شخصياتهم لا سيما إذا كان قد تقدم في درجات التعليم والمركز الاجتماعي بينما أسرهم كان نصييها من الدراسة محدوداً ومراكزها الاجتماعية أقل من طموحهم. 


\section{كلية التربية للطفولة المبكرة- جامعة بني سويف}

ه- القيود التي تفرضها الجامعة والتي تحول بين المراهق الثاب وبين تطلعه إلى التحرر وقد تكون ثورة الشباب على أساتذتهم على شكل اندفاع في الكلام لمعارضة آرائهم (إقبال

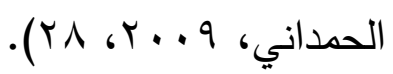

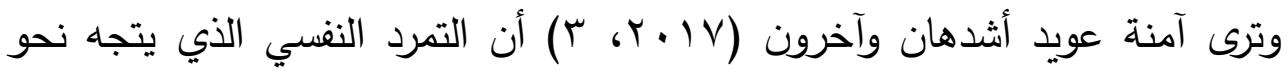
التسلط الهنتيري والتعليمي قد يكون راجع إلى جهل الآباء والمربين بالأساليب الصحيحة للتربية وعدم الفهم والإدراك السليم لخصائص وطبيعة المرحلة، حيث يظهر الأبناء سخطهر للكبار لآباء يعانون من افتقارهم إلى النموذج الذي يساعدهم على الاستقرار الداخلي ومواجهة أي تغيرات اجتماعية.

أنواع التمرد النفسي:

من المعلوم أن الطفل في مرحلة الطفولة المتأخرة يسعى إلى تحديد هويته فهو في هذه المرحلة يرغب في الخروج من حيز الأسرة وإتباع سلطة الوالدين ويبدأ أن يبحث كيف ييني نفسه ليصبح شخص فعال في المجتمع، ففي هذه المرحلة يبدأ التفكير المجرد ويضع فروض أمامه ويحاول أن يحققها، لذلك فهو يرفض أن يملي عليه أحد وجهة نظرهم، لذا فهو من هنا يعلن تمرده، فهو يريد أن يثبت لهم أنه قادر على اتخاذ القرار ولديه القدرة على أن يبحث عن ذاته فهو بداخله طاقة ونشاط ولكن الأهل لا يرون ذلك وهذا يعتبر نوع من التمرد الإيجابي وقد يتواجد هذا النوع من التمرد عن كل الأبناء فى مرحلة الطفولة المتأخرة سواء من الأفراد العاديين أو من ذوي الإعاقات البصرية فهم أيضاً لديهم القدرة على رسم مستقبلهم ويكون بداخلهم طاقة كبيرة ليحقق ما يرسمونه لطريقهم المستقبلي لكن في بعض الأحيان قد تعقف الإعاقة في مستقبلهم فهم يحتاجون إلى مد يدهم للعون والمساعدة في بعض الأمور، وهناك منهم من يكون لديه العزيمة والإصرار لتخطي كل الصعاب دون أي مساعدة تذكر 
وهنا أو لذلك فسوف نذكر أشكال التمرد الذي يمر بها هؤلاء الأبناء عن المبصرين وغير

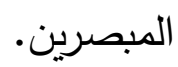

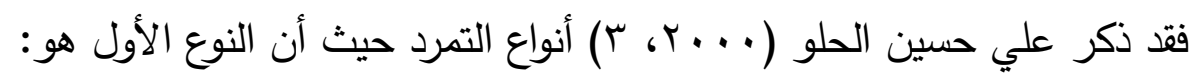
الاتجاه السلبي: وهو نوع هدام وضار ويعد هذا النوع من أصعب الشثكلات السلوكية التي

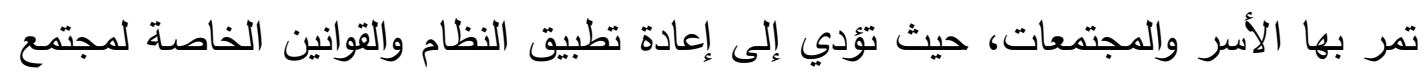
حيث تظهر مظاهر التمرد النفسي السلبي داخل الأسرة ويبدأ الابن الامتتاع عن تتفيذ أوامر

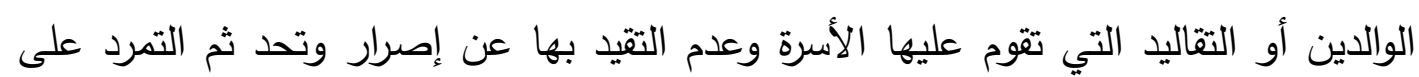
الحياة المدرسية وإتمام الواجبات والالتزام بالذي وكل ما يثبه ذللك. أما الاتجاه الثاني وهو الاتجاه الإيجابي وهو الغرض منه الإسهام في تطوير المجتمع والدفاع عن مصالح المجتمع والبيئة التي يعيش فيها. فالأسرة التي تمتاز بالأسلوب المرن والتثجيع على تحمل المسئولية التي بدورها تخلق

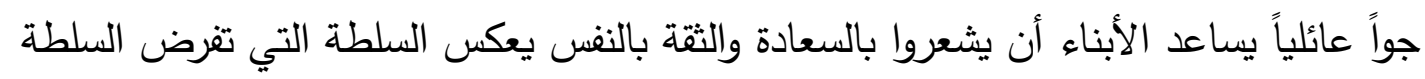
والقوانين.

كما وضح جاك بريم (974) أن التمرد النفسي ظاهرة نفسية عندما اهتم بالمواقف

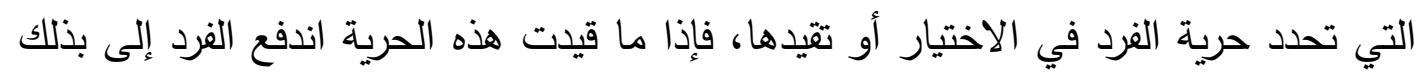

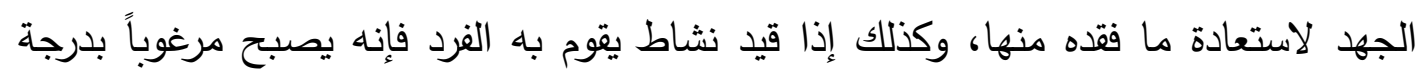

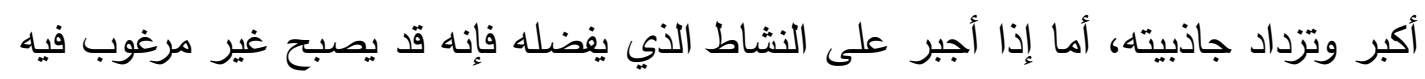

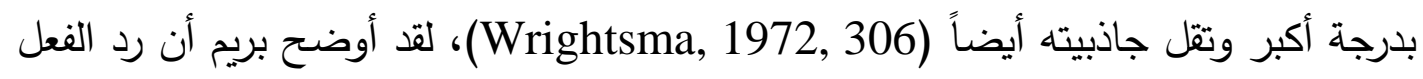
النفسي هو قوة دافعية يعتقد أنها تنثأ عندما تقلل أو تقلص الحريات الثخصية للفرد أو

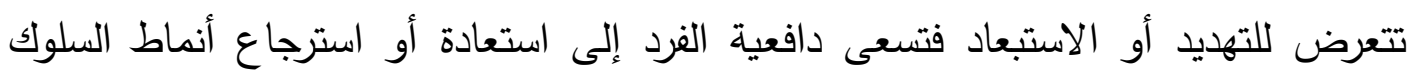

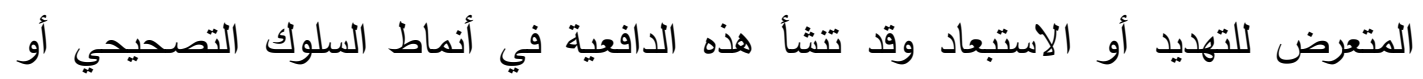
1657

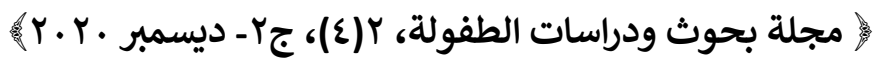




\section{كلية التربية للطفولة المبكرة- جامعة بني سويف}

التعويضي والمعروف (بآثار رد الفعل) ويمكن أن يعبر عنها الفرد سلوكياً أو إدراكياً أو

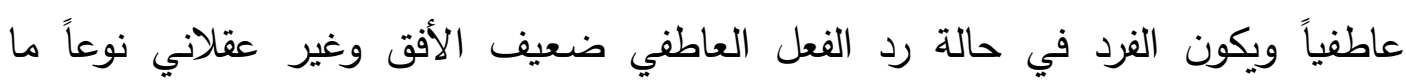
(Buboltz \& Walter, 2001, 1)، ويرى بريم أن حجم التمرد يتوقف على العوامل الآتية: • (أهمية السلوك الحر الزائل أو المهدد بالإزالة. • (- منسة السلوك الزائل أو المهدد بالإزالة.

• حجم هذا التهديد إذا كان هناك تهديد بإزالة السلوك فحسب (Brehm, 1966, 3). وبعد التبرير والمشروعية عاملان يتسمان بالتعقيد من وجهة نظر بريم ولهما تأثير من

ناحيتين:

1- التأثير في حجم التمرد الدستثار بفقدان الحرية. r- التأثير في القيود ضد آثار التمرد.

فإذا أمر شخص ما شخصاً آخر للقيام بعمل يتعلق بتهديد حرية معينة لديه، فهنا يعني ضمناً تهديد لحريات أخرى، لكن إذا أعطي الثخص تبريراً مقنعاً لثخص الآخر مبيناً سبب المنع لظرف معين، فالتهديد في هذه الحالة يمس القليل من الحرية ولا يزيد من درجة التمرد لاى الفرد طالما إن هناك مشروعية للمنع، كأن يمنع الأب ابنه من التأخر والسهر ليلاً مع أصدقائه نتيجة لظروف أو وضع معين (Brehm, 1981, 12).

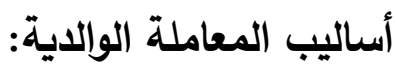
وتعد المعاملة الوالدية من بين أهم محددات تتمية المرونة والسواء النفسي العام لاى الأبناء وإذا كان من الثابت أن المعاملة الوالدية المختلفة وظيفياً أو القائمة على الإهمال

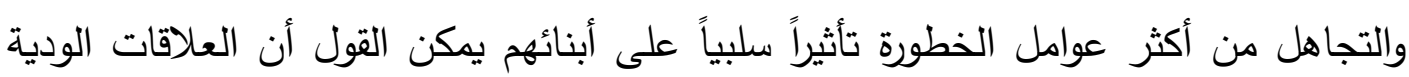

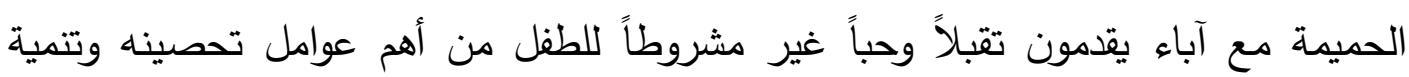


مناعته النفسي العامة ضد الاضطرابات النفسية المختلفة وضد المشكلات الأخرى في مراحل

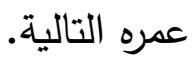

من أهم النماذج النظرية المستخدمة في وصف وتصنيف أساليب المعاملة الوالدية ما يسمى بنموذج التصنيف ذو البعدين: درجة الاندماج مع الأطفال ودرجة المطالب من الأطفال،

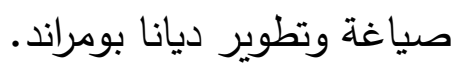

والآباء الكندمون هم الآباء الذين: يهتمون بصورة كبيرة بأطفالهم، الحساسون لمطالب واحتياجات أطفالهم، والمندمجون بلطف وود في حياة أبنائهم والآباء غير المندمجون من ناحية ثانية، هم الآباء المبتعدون عن أبنائهم المتجاهلون لاحتياجاتهم ومطالبهم. أما فيما يتعلق ببعد المطالب فنجد أن الآباء كثيروا الدطالب هم الآباء الذين يتبنون

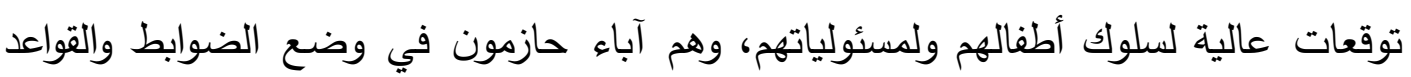
والحدود. في المقابل الآباء قليلو المطالب يتبنون توقعات منخفضة لأطفالهم، ويسحون الهاه لأطفالهم بنطاق واسع من الحرية، ولا يفرضون أو لا يضعون إلا حدود أو قواعد قليلة جداً. تعريفات أساليب المعاملة الوالدية:

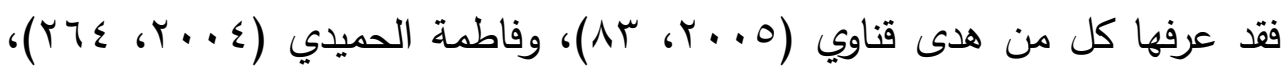

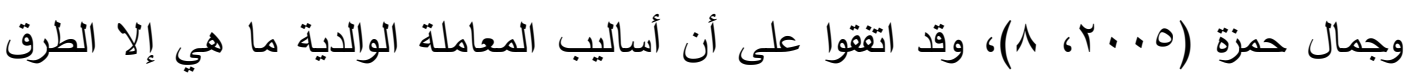

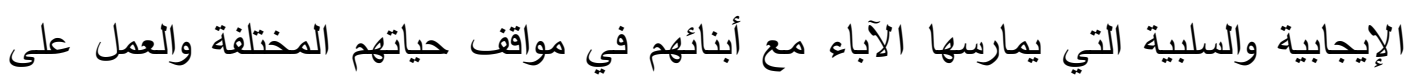
غرسها بداخلهم مع التمسك بالعادات المجتمعية وتقاليدها وهي تقاس عن طريق تعبه لهبير الوالدان

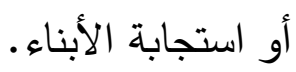

ومن خلال قراءة الباحثة للتعريفات السابقة يتعرف أساليب المعاملة الوالدية بأنها الأساليب التي يتبعها الآباء مع الأبناء سواء كانت إيجابية وتساعد على نمو الابن في الاتجاه

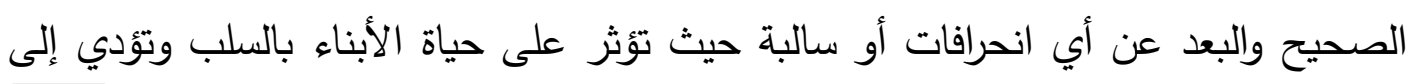
1659

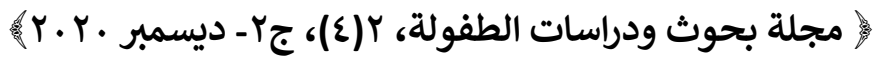




\section{كلية التربية للطفولة المبكرة- جامعة بني سويف}

حدوث الانحراف في جميع جوانب حياة الابن وبالتالي لم يصبح لديه القدرة على التكيف الاجتماعي وحدوث خلل في شخصيته وهذه الأساليب يتبعها الآباء في جميع المراحل العمرية المختلفة وفي المواقف الحياتية بصفة عامة سواء من العاديين من الأبناء فى مرحلة الطفولة المتأخرة أو ذوي الاحتياجات الخاصة من أبنائهم المكفوفين.

Ellen G. فقد جاءت دراسة (2019) فeried Ferial M. et al. ودراسة (2016)، ودراسة (2011) Tanzila and Amyad Rehman حيث هدفت إلى التحقق من أساليب معاملة الوالدين لأبناء المعاقين بصرياً حيث قيمت آثار أنماط الوالدين لدى أبنائهر من خلال تطبيق استتبيان السلطة الوالدية، وقد أظهرت نتائج الدراسة على أن أكثر من نصف الأبناء فى مرحلة الطفولة المتأخرة ينظرون إلى أساليب الوالدين على أنها شوري والبقية ينظرون إلى الأبوة على أنها استبدادية بنسبة † \% أو متساهلة بنسبة 0 \% وأن استخدام تلك الأساليب معلم من مرحلة الطفولة قد أثرت كثيراً في شخصيتهح وقد ينظرون معظم الأبناء المكفوفين إلى آبائهم على أنهم ذوو سلطة. وكما وضحت الأبحاث السابقة أن هناك اختلاف في مستويات إدراك الأبناء لأساليب المعاملة الوالدية وذلك بسبب أوضاعهم الصحية أو الحسية، ومن خلال إطلاع الباحثة فقد وجدت الباحثة عدد قليل من الأبحاث التي ركزت على نقص المشكلات السلوكية للمراهقين من ذوي الإعاقة البصرية وأثثر المعاملة الوالدية على تلك الفئة من الأبناء وهل النمط المستخدم مع هؤلاء الأبناء قد أثر في شخصيتهم في المراحل الأخرى من النمو وكان له الأثر في حدوث التمرد النفسي أم لا.

وقد تعددت الأبحاث التي درست أساليب المعاملة الوالدية لتلك الأبناء من ذوي الإعاقات المختلفة وأثرها على المتغيرات النفسية المتعلقة بهم بالرغم من أنها أقل بكثير من الدراسات التي تمت على الأبناء العاديين. 


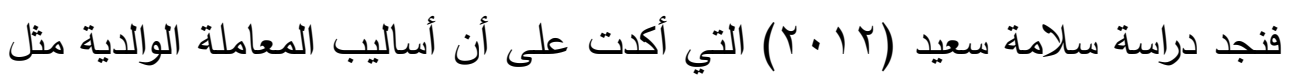
(الحماية الزائدة التحكم والسيطرة والتثرقة والتنبذب) والأساليب الأخرى السوية قد ارتبطت ارتباطاً وثيقاً بأساليب التوافق لدى الأبناء الصم فى مرحلة الطفولة المتأخرة وقد أكدت نتائج دراستها على أنه يوجد فروق ذات دلالة إحصائية بين الأبناء الذين يلقون معاملة والدية سوية من الوالدين والأبناء الذين يلقون معاملة غير سوية لصالح الأبناء الذين يتلقون المعاملة

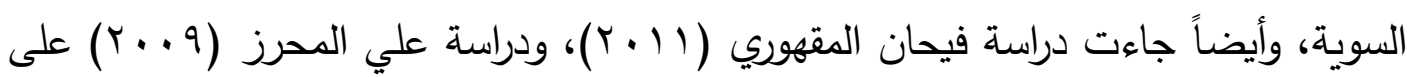

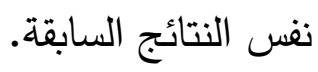

فقد تتأثر أساليب المعاملة الوالدية للأبناء بالثقافة السائدة في مجتمع معين كما يتأثر بعدة متغيرات شخصية يتعلق بالآباء والأمهات أنفسهم كالسن والجنس والمستوى التعليمي وقد

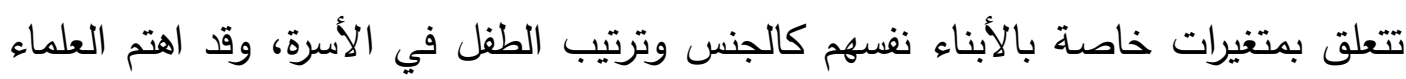

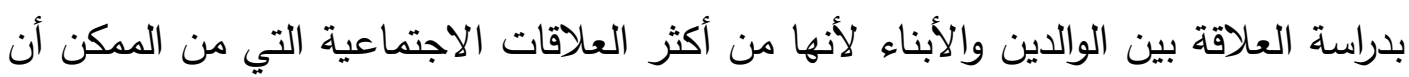
تؤثر في شخصية الأبناء.

فقد أكدت دراسة الظاهرة محمود المغربي علي (19 (Y) على أن وجود العلاقة الموجبة التي تقدم على أساليب المعاملة الوالدية السوية قد تؤدي إلى النجاح في تربية الأبناء

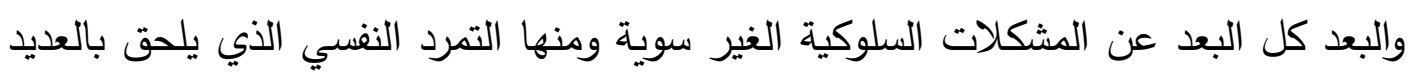
من الأبناء وخاصةً في مرحلة المراهقة. وتعدد أساليب المعاملة الوالدية أدى إلى أن لا تأخذ شكل واحد من الأشكال، إنما

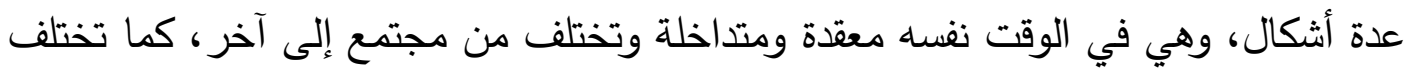

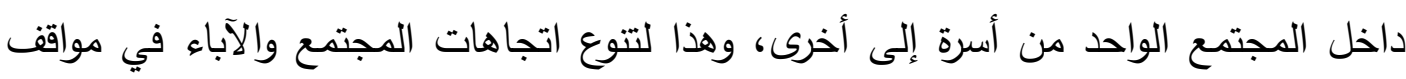

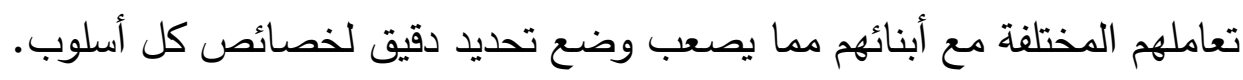




\section{كلية التربية للطفولة المبكرة- جامعة بني سويف}

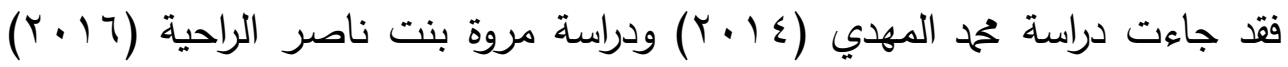
حيث هدفت دراسة على التعرف على العلاقة بين المشكلات السلوكية في ضوء بعض أنماط التتشئة الاجتماعية وكانت من نتائجها أن جاءت المشكلات السلوكية الأولى من حيث الترتيب، وكانت من نتائجها أيضاً وجود علاقة ارتباطية بين نمط المعاملة الوالدية وسلوك الأبناء. وسوف نذكر شيء من التوضيح لأساليب المعاملة السلبية والإيجابية محور الدراسة

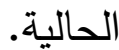

\section{تعددت الاتجاهات الوالاية وحددها البعض في عدة نقاط كما يلي:}

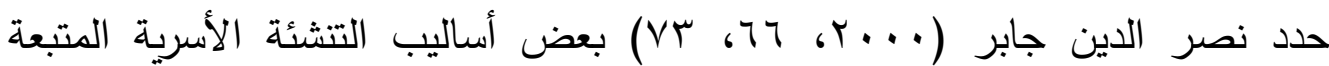
وتتضمن أساليب المعاملة المرتبطة بك ما يلي:

$$
\text { צ- צ- التماية الزائدة. }
$$

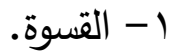$$
\text { ب- - (التذبذب (عدم الاتساق). }
$$

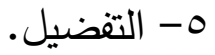

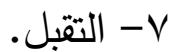

وقد حددها وفيق صفوت مختار ( V) . . أن أساليب تربية الطفل يمكن تحديدها وفقاً

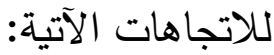

r- اتجاه التساهل والإهمال.

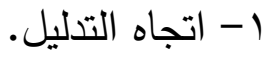
ع - اتجاه الرفض والنبذ.

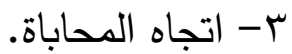

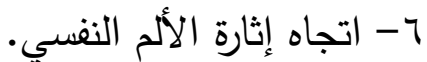

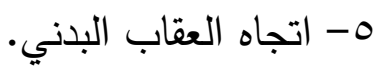
^- اتجاه التفرقة والتمييز بين الأطفال. V- اتجاه فرض الحماية. . 9- اتجاه التسلط. r ا - اتجاه التذبذب.

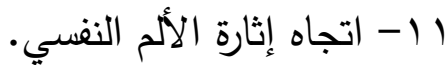




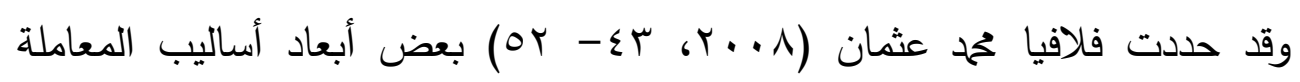

$$
\begin{aligned}
& \text { r- التسامح والتساهل. } \\
& \text { 1- التدليل والحماية الزائدة. } \\
& \text { ع - التثرقة في معاملة الأبناء. } \\
& \text { r- النبذ والرفض والإهمال. } \\
& \text { 0- الحرية في التعامل (المرونة والحزم). ؟- السيطرة والقسوة وتقيد حرية الأبناء. }
\end{aligned}
$$

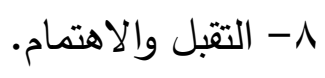

$$
\begin{aligned}
& \text { - V التذبذب في معاملة الطفل. } \\
& \text { 9- بث القلق والثعور بالذنب. }
\end{aligned}
$$

حتى يشعر الفرد بالطمأنينة والثعور بالأمان مما ينمي لديهم الثعور بالثقة بالنفس

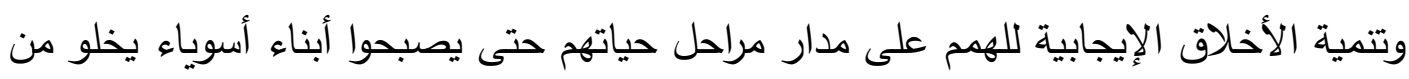
المشكلات السلوكية.

ويعد تقبل الأبناء وبالأخص من ذوي الاحتياجات الخاصة واحدة من أهم شروط

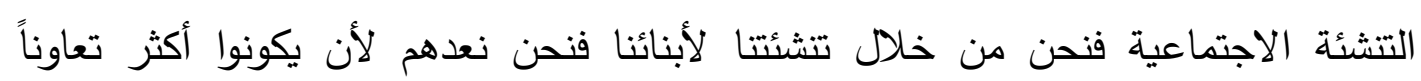
واستقرارً وثقة بالنفس.

\section{[1] [أساليب المعاملة الوالدية الإيجابية:}

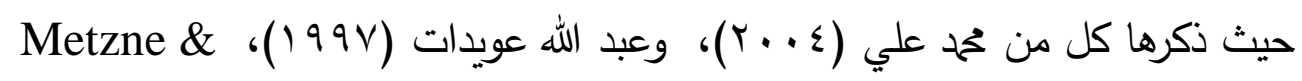

.Steinhousn (1999)

\section{1- أسلوب التقبل:}

والمقصود هنا أن يشعر الطفل بأن والديه يشعرون بالسعادة والرضا والارتياح عند

تواجه معهم وأن من المفروض أن يتقبلونه كما هو حتى إذا كان هذا الطفل من أطفال ذوي

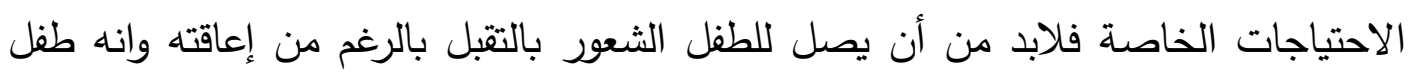
مرغوب فيه ذاتياً وعكس التقبل هو الرفض وأن التقبل من أهم احتياجات الإنسان. 


\section{r- أسلوب الإرشاد التوجيهي:}

إن من أهم وسائل التربية التي تؤثر في شخصية الأبناء هي التربية بالنصح والإرشاد

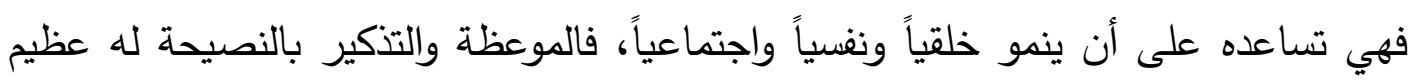
الأثر في تعليمهم وإكسابهم العديد من حقائق الأشياء.

فقد جاءت دراسة سعد خبيان الماجدي (9 ( ب) حيث هدفت الدراسة إلى التعرف على أهم أساليب المعاملة الوالدية كما يدركها الأبناء وعلاقتها بالسلوك العدواني، وقد طبقت الته

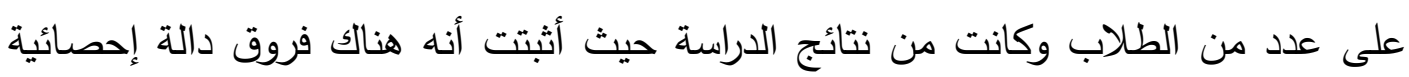

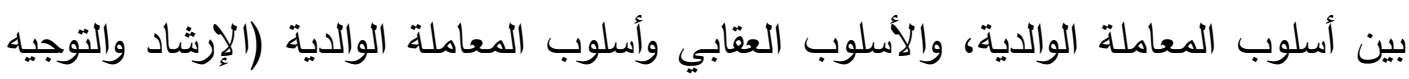
كما يدركها الأبناء لصالح أسلوب التوجيه والإرشاد).

\section{ب- أسلوب المساواة في المعاملة:}

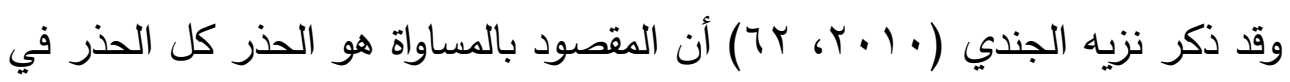
معاملة مواقف الحياة المختلفة وعدم التثرقة بين الأبناء في كافة جوانب الحياة كالمأكل والملبس والمشاركة في الأنثطة حتى ينشأ هؤلاء الأبناء بصحة نفسية جيدة فهذا النوع من فيناء فئه

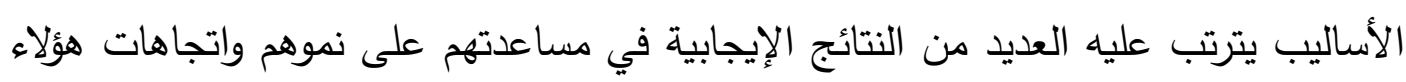
الأبناء تجاهها آبائهم والآخرين في المجتمع الذين يعيشون فيه، مما يترتب عليه شعور الأبناء

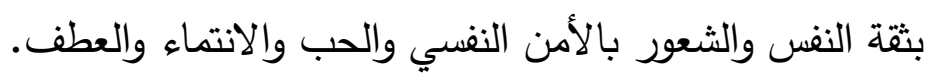
وقد أكدت على القول السابق دراسة فتيحة مقحوت (ع ا.ب) على أهمية استخدام أساليب المعاملة الوالدية السوية وأن الوقوف على هذه الأساليب قد يساعد في تحقيق الصحة

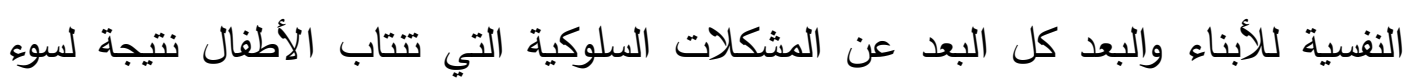
معاملتهم.

[ [ [ أساليب المعاملة الوالاية السالبة: 
- أسلوب الرفض:

وقد ذكر بطرس حافظ (r (r) حيث أن أسلوب الرفض الذي يتعامل به الأبناء مع

أبنائهح يشتمل على نوعين مختلفين فالنوع الأول هو رفض شبه دائم أي يظهر ذلك في الحالات التي لا يشعر الآباء بحبهم لأبنائه وقد يرجع ذلك إلى عدم تقبل الوالد لأبنائه وقد يكون النوع الثاني في شكل تجاهل لمتطلبات ورغبات الأبناء أي إهمالهم سلسلة احتياجاتهم فدائماً هذا النوع من الآباء كثير التوبيخ بأبنائهم والتقليل من شأنه وكثير السخرية من

تصرفاتهم.

\section{r - ب أسلوب الحماية الزائدة:}

قد عرفه كل من فضيلة عرفات السبعاوي (·( •؟، T)، وقحطان أحمد الظاهر

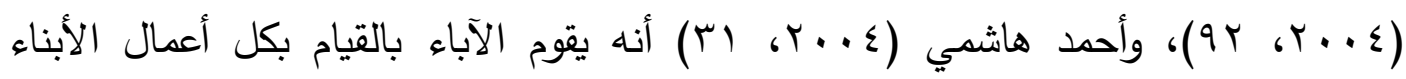
بالنيابة عن أبنائهم والتي لابد ومن المفروض أن يتدرب الطفل عليها حتى يصبح لديه شخصية مستقلة فلابد أن يمارس الأبناء حقوقهم وتكون لديهم حيزا لحرية في اتخاذ القرارات التي تتناسب مع أعمارهم الزمنية. كما أنه يؤدي الإسراف في حماية الطفل إلى اتجاه شخصية الابن إلى الاعتمادية والتبعية في كل أمور حياته مما يؤدي إلى عدم تحمل المسئولية فيها بعد ويجد صعوبة في الإني مواجهة المشكلات التي تعرض لله وأنه دائهاً أبداً يحتاج إلى من يساعده على التغلب على مشكلاته الثخصية وبالتالي يصبح الابن دائماً يشعر بعدم الأمان والطمأنينة إذا غاب عنه والدياه. 
ب- أسلوب التساهل الثديد:

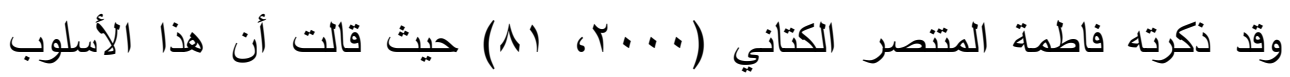
يستخدم الآباء ويعمل على مساعدة الطفل وتثجيعه لكي يحقق رغباته بالثكل الذي يرضيه، مع الاستجابة المستمرة لمطالبه، وغياب تطبيق الثواب والعقاب، منها النوع من الأساليب لئل يتغير بالشعور بالدفه والبعد عن الصرامة في التعامل مما قد تؤدي بالطفل إلى شعور

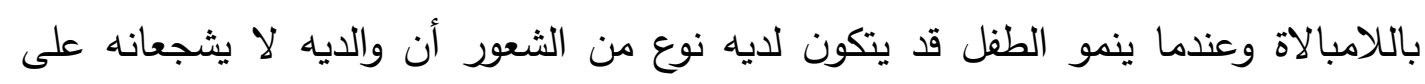
اكتشاف شخصيته.

\section{العوامل المؤثرة في أساليب المعاملة الوالدية:}

قد تختلف أساليب المعاملة الوالدية من أسرة لأخرى ومن مجتمع لآخر، وهذا تبعاً للعوامل التي تؤثر فيها (المعاملة الوالدية) حيث تلعب دوراً هاماً في تربية الأطفال وهذه

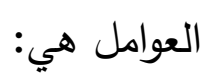

فقد نجد أن أثر حجم الأسرة حيث يختلف الوضع ما بين عدد أفراد الأسرة في الأسرة الكبيرة العدد يتسم بالمعاملة فيها بالإهمال لأنه يصعب الاهتمام بأمور كل طفل وعلى العكس إذا كان حجم الأسرة صغير الحجم، كما أن الحب والمساندة الانفعالية من الآباء لأطفالهم تقل وتتعدم في الأسرة الكبيرة وفي الأسرة الكبيرة أيضاً ينشأ الأبناء لديهم استقلالية واعتماد شديد على النفس ولكن تتسم الأسرة صغيرة الحجم بالتعاون المتبادل بين الآباء والأبناء فيسود

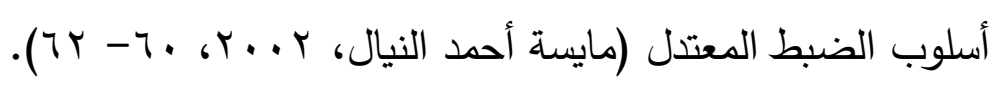

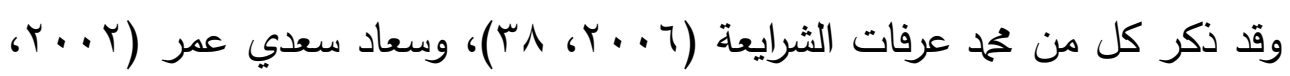

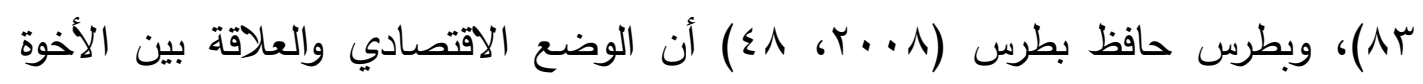
والعوامل الثقافية لها دور في التأثير على أسلوب المعاملة مع الأبناء فنجد أن الوضع الاقتصادي قد يؤثر تأثيراً شديداً في تتشئة أفراد الأسرة مما تؤدي إلى فرض أسلوب معاملة 
معينة مع أبنائهر كما أن العلاقات الموجودة بين الأخوة وبعضهم وهل يختلف أسلوب المعاملة مع طفل لطفل آخر وهل يسود حياتهم حالة من الانسجام أم هناك تتافس بينهم نتيجة لأسلوب المعاملة مع كل منهم على حدى كل من هذه العوامل قد تؤثر تأثيراً شديداً ويمكن أن نذكر تلك العوامل في نقاط مختصرة:

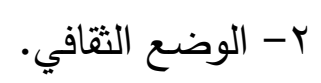

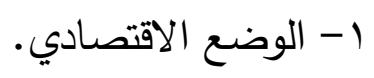

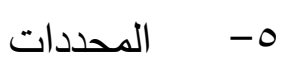

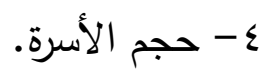

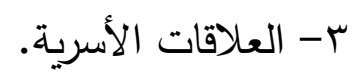

النفسية.

وتأكيداً على دور تلك العوامل أو المحددات وأثرها في استخدام أساليب المعاملة الوالدية سواء كانت من الأساليب السلبية أو الإيجابية وبالأخص من الأبناء من ذوي الاحتياجات الخاصة الذين هم مثلهم مثل أقرانهم العاديين بحاجة إلى استخدام أسلوب أمثل للتعامل معهم دونت أن نخلق مشكلات نفسية غالباً يكون سببها الآباء فقد نجد العديد من الدراسات التي أكدت على أهمية استخدام أساليب المعاملة مع تلك الفئة، فقد نجد دراسة

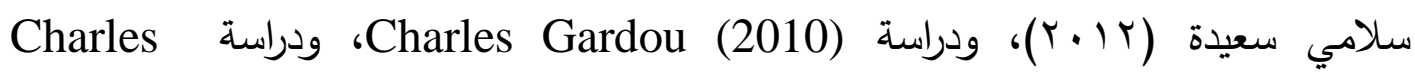
(2012) (Gardou (إن معظم هذه الدراسات اهتمت بدراسة المعاملة الوالدية وتأثيرها على شخصية أبنائهم وبالأخص لاى الأبناء المعاقين من حيث قبولهم ورفضهم للإعاقة وأثر كل ذلك على النمو النفسي للأبناء، أما فيما يخص البحث الحالي فسوف نخص بالبحث فئة المكفوفين للتعرف على العلاقة بين أساليب معاملة الوالدين السوية والغير سوية في تربية أبنائها وعلاقتها بالتمرد النفسي عند هؤلاء الأبناء.

\section{() نظرية التحليل النفسي في التشئية الاجتماعية:}

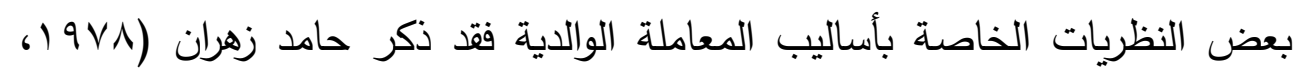

ء 7) أن صاحب هذه النظريات العالم المعروف سيجموند فرويد، فقد يرى أن أساس تتشئة 


\section{كلية التربية للطفولة المبكرة- جامعة بني سويف}

الفرد الاجتماعية ما يطلق عليه الأنا الأعلى وقد أطلق عليه ذلك نظراً لتطوير الطفل حيث يقوم الطفل بالأدوار التي يقوم بها والده، وقد أكدت هذه النظرية على أن الآباء يحاولوا أن يتصدوا لغرائز الطفل محاولين أن يتطبع بعادات وتقاليد المجتمع الذي يعيش فيه ولكن إصرار الآباء على ذلك قد يؤدي إلى حدوث كراهية الأبناء لوالديهح ولكنهم يقومون بتنفيذ ما يطلب منهم خوفاً من العقاب وتجنب القلق والشعور بالذنب.

\section{r) نظرية التعلم في التنشئة الاجتماعية:}

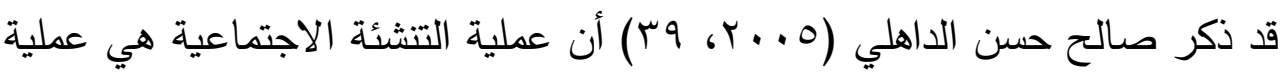
تعلم في حد ذاتها حيث تتضمن تغيراً في السلوك وذلك يتم نتيجة التعرض للخبرات من خلال التنشئة التي يعيش فيها الإنسان، فقد ترى هذه النظرية أن عملية التطور الاجتماعي يحدث كما تحدث عملية تطوير أو تعليم الطفل للمهام الحياتية وذلك يتم من خلال ملاحظة الآخرين ومحاولة تقليدهم كما أن هناك دور كبير في استخدام مبادئ التعليم وهي التعزيز والعقاب خاصة في عملية التنشئة الاجتماعية.

r) نظرية الاور الاجتماعي في التنشئة الاجتماعية: فقد ذكرها عبد العزيز خواجة (0. . . ، VA) على أنه قد يكون لكل فرد دوراً اجتماعياً في المجتمع الذي يعيش فيه ولكن تختلف الأدوار والمهام كل على حسب، فالدور يحدده السن والجنس والمكانة الاجتماعية والثقافية، ويعد الدور الاجتماعي الجانب الديناميكي للمركز الاجتماعي وما يقوم به من حقوق وواجبات فهي تقوم على مفهومين رئيسيين هما المكانة الاجتماعية، والدور الاجتماعي. وقد ركزت الباحثة على هذه النظريات حيث أنها الأقرب إلى موضوع البحث. خلاصة القول أن جميع الآباء مهتمون بأبنائهم وبأمور حياتهم محاولين التعامل معهم في ضوء ما يتصورا أنه أفضل أسلوب للتربية ولكن حقيقة أن هذه الأسلوب هو الأسلوب 
الأمثل أولاً قد يتوقف على إدرالك هؤلاء الأبناء لتلك المعاملة فهم هؤلاء الأبناء هم محور

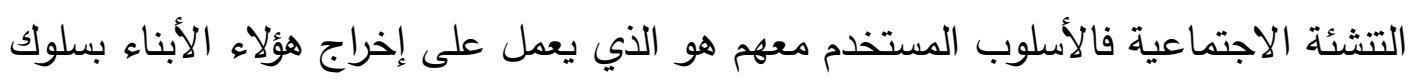

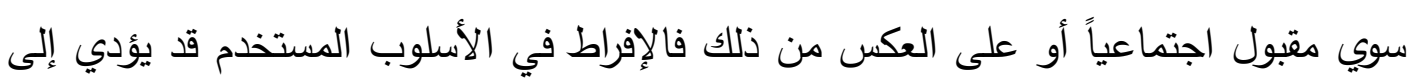

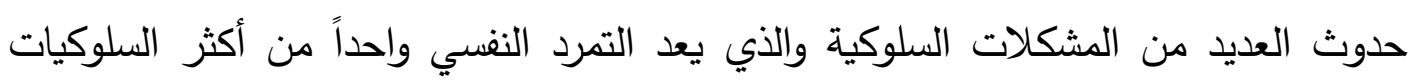

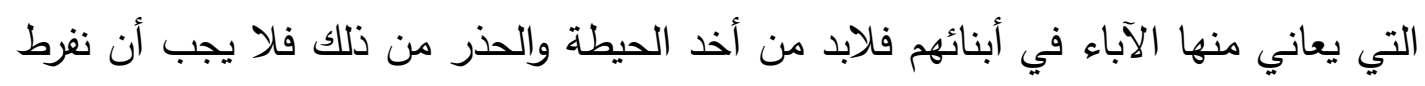

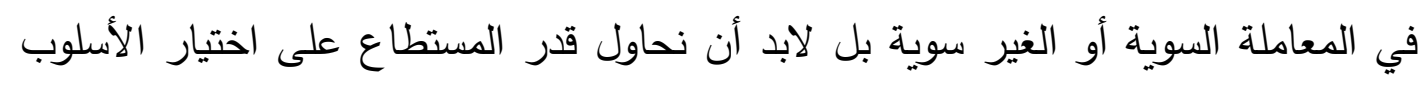

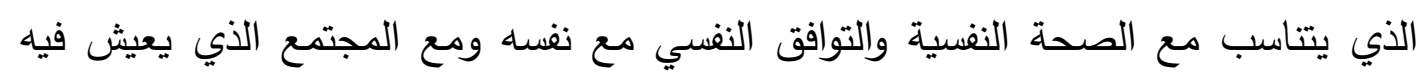
وبالأخص إذا كان هذا الابن من ذوي الاحتياجات الخاصة.

\section{الاجراءات المنهجية للدراسة:}

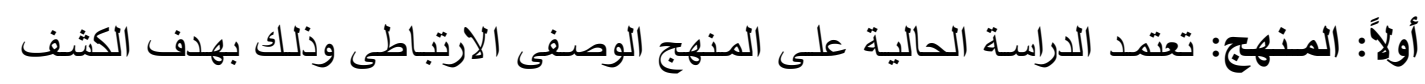

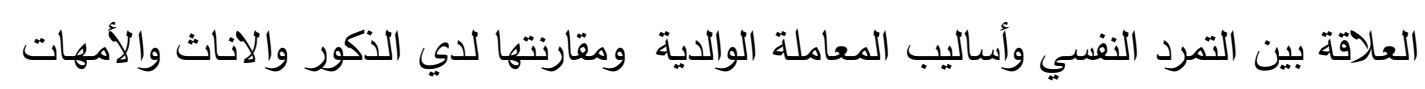

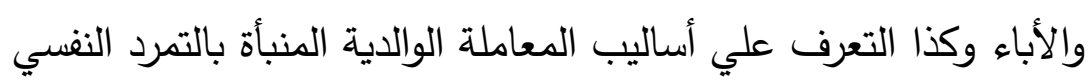
ثانياً :عينة الدراسة

\section{[ أ ] [ينة الداسة الاستطلاعية:}

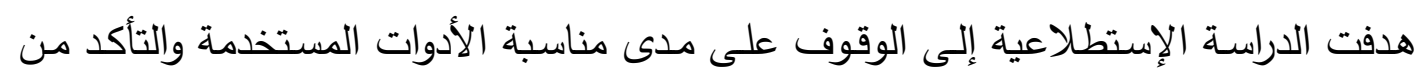

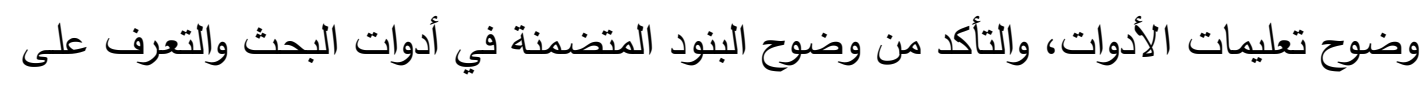

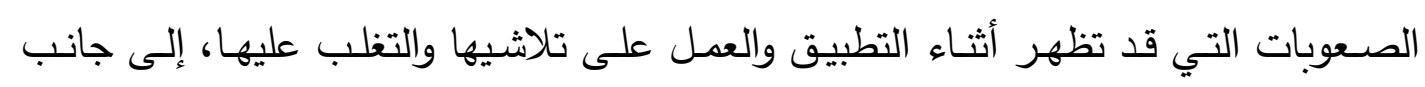
التحقق من صدق وثبات أدوات البحث ـ ولتحقيق هذه الأهداف قامت الباحثة بتطبيق أدوات

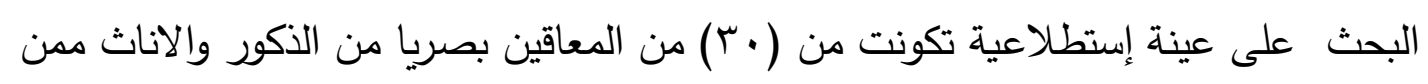

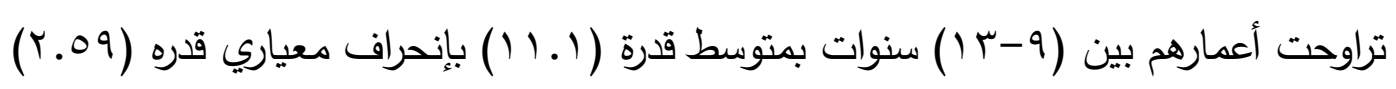




\section{[ب] عينة البحث النهائية (الأساسية):}

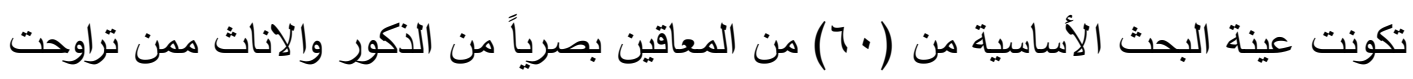

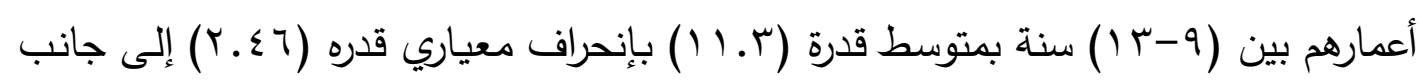
عينة من الأباء والأمهات ثالثاً:أدوات الدراسة: من الاباء أولاً: مقياس التمرد النفسي من اعداد الباحثة. قامت الباحثة باعداد مقياس التمرد النفسي حيث وجدت الباحثة ندرة فى الأدوات التي تقيس التئه التمرد النفسي فى البيئة الدصرية والعربية.. خطوات إعداد المقياس: مر بناء المقياس بعدة خطوات:الخطوة الأولى : اطلعت الباحثة على ما أتيح لها من إطار نظرى ودراسات سابقة وبحوث بطاه

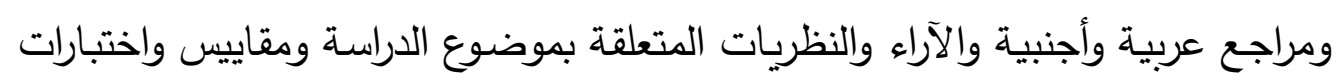
التى تناولت التمرد النفسي من أجل التعرف على طرق والأدوات المستخدمة والاستفادة

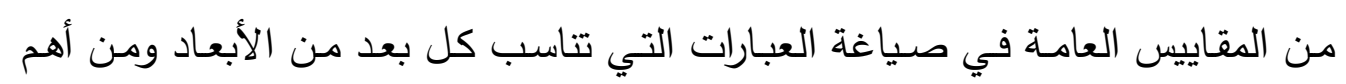
المقاييس التي اطلعت عليها الباحثة: الخطـوة الثانيـة: بعد إطـلاع الباحثة على المقـاييس السـابقة والإطـار النظري واللقـاءات

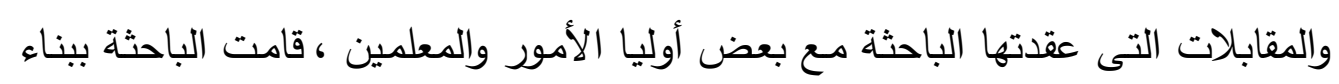

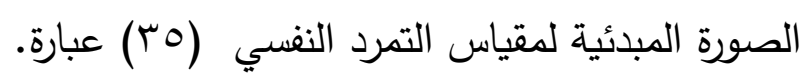

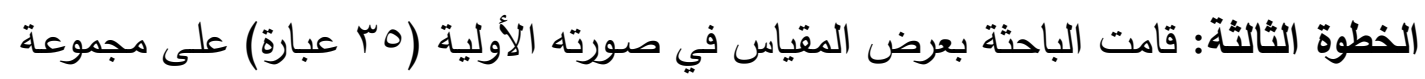

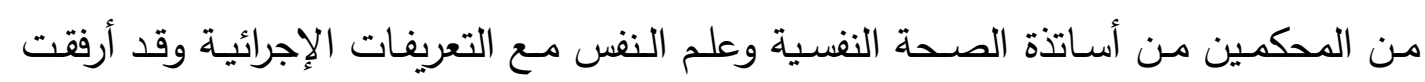

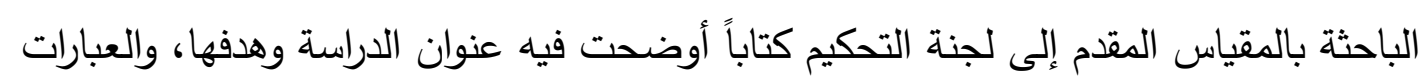

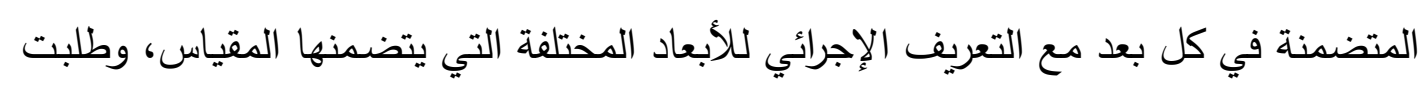

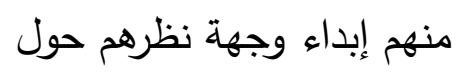


- مدى اتفاق بنود المقياس مع الهدف الذي وضعت من أجله.

- إرتباط المفردات بالأبعاد المرجو قياسها فى ضوء التعريف الإجرائى لكل بعد.

- مدى مناسبة العبارة لطبيعة العينة.

- الحكم على مدى دقة صياغة العبارات ومدى ملاءمتها لأبعاد المقياس.

- - - إبداء ما يقترحونه من ملاحظات حول تعديل أو إضافة أو حذف ما يلزم.

وفي ضوء توجيهات السادة المحكمين قامت الباحثة بما يلي:

• •

• تعديل العبارات بحيث تتضمن موقفاً واضحاً.

فك العبارات المركبة.

حذف العبارات التي توحي بإجابة معينة.

حذف بعض العبارات التي لم تصل نسبة الاتفاق فيها على ر^\% من عدد

المحكمين ومن ثم أصبح عدد بنود المقياس (• (r) عبارة بدلاً من (هب) عبارة.

الخطوة الرابعة: قامت الباحثة بدراسة استطلاعية بتطبيق المقياس على عينة من الأطفال المعاقين بصريا للتعرف علي أهم الصعوبات أو العوائق التي قد تواجه الباحثة أثناء تطبيق المقياس ووضع بعض التعديلات لحلها أو تفاديها وكذا لمعرفة مدى مناسبتها للمستوى اللغوي لهم. وقد روعي أثناء التطبيق تدوين الملاحظات التي أبداها أفراد العينة والتي تبدو في عدم فهم معاني بعض الكلمات وقد تم تعديلها بالصورة المناسبة حتى يسهل عليهم فهمها والإجابة عليها بسهولة. وقد حققت التجربة الاستطلاعية الأهداف التالية: مناسبة المقياس لعينة الدراسة من حيث المحتوي المقدم في المقياس

$$
\text { مناسبة عدد البنود }
$$

الزمن المناسب لتطبيق المقياس

تحديد المكان المناسب للتطبيق 


\section{كلية التربية للطفولة المبكرة- جامعة بني سويف}

قامست الباحثة بحسـاب الخصسائص السيكومترية للمقياس للاطمئنسان علي استخدامه فى الاراسة الحالية بالطرق التالية:

ا- صدق المحك الخارجي: قامت الباحثة بحساب معامل الارتباط بين درجات مجموعة من المفحوصين(ن= • ب) على مقياس التمرد النفسي من اعداد الباحثة المستخدم فى الدراسة ومقياس التمرد النفسي من اعداد ياسره حمح أبو هدروس وبلـغ معامل الارتباط بين درجات الأفراد على المقياسين ع ع . . وهي دالة احصائيا عند مستوي ا .. . وهو معامل صدق يعزز الثقة فى المقياس. r- الاتساق الداخلى للعبارات: قامت الباحثة بحساب معاملات الارتباط بين درجة كل عبارة والدرجة الكلية للبعد (ن= • ب) والنتائج مبينة فى جدول (1): جدول(1)

درجة الارتباط بين كل عبارة والدرجة الكلية للبعد ن= • ب

\begin{tabular}{|c|c|c|c|c|c|}
\hline معامل الارتباط & 5 & معامل الارتباط & 5 & معامل الارتباط & 5 \\
\hline$* *$ *. $\leqslant 97$ & r & $* * .097$ & r & $* *$ *. \10 & 1 \\
\hline **. .or. & 7 & $* * . .7 \leq 7$ & 0 & $* * .071$ & $\varepsilon$ \\
\hline$* * .090$ & 9 & $* * .00 \mathrm{~V}$ & $\wedge$ & $* * .09 \varepsilon$ & V \\
\hline$* * .011$ & ir & $* * .70 \leqslant$ & 11 & $* *$. . \^V & 1. \\
\hline$* *$ *. \人० & 10 & $* * .00 \mathrm{~V}$ & $1 \leq$ & $* * .770$ & M \\
\hline **..VYY & 11 & **..VYr & IV & $* * .779$ & 17 \\
\hline$* * . . \vee Y q$ & YI & $* * .790$ & $r$. & $* *$ *. YYo & 19 \\
\hline$* * .0 Y$. & $r \varepsilon$ & $* * .701$ & سץ & $* * .00 \leqslant$ & rt \\
\hline **, Ү & rV & $* * . \vee 10$ & $r y$ & $* * \ldots \leqslant \vee 1$ & ro \\
\hline$* *$ * . \^० & r. & **. . orr & rq & $* * . .71 \leq$ & rᄉ \\
\hline
\end{tabular}


الثبات: قامت الباحثة بحساب ثبات مقياس التمرد النفسي باستخدام الطرق التالية: (أ) معادلة ألفا كرونباخ: وذلك على عينة بلغت(· ·) من المفحوصين، وكانت النتائج كما

$$
\text { هي ملخصة فى جدول(1) (1) }
$$

(ب) طريقـة التجزئـة النصفية: وتم التصـيح باستخدام معادلة سبيرمان براون على عينـة

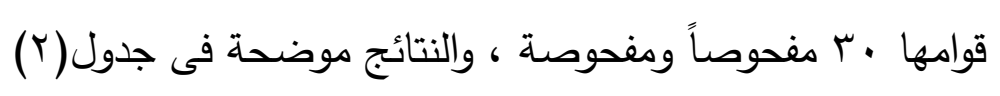

$$
\text { جدول(r) (r) (r) }
$$

\begin{tabular}{|c|c|c|}
\hline التجزئة النصفية & ألفا كرونباخ & الأبعاد \\
\hline$\cdot \wedge \leqslant 1$ & . . & الدرجة الكلية \\
\hline
\end{tabular}

معاملات الثبات بطريقة ألفا والتجزئة النصفية ن= . ب

ثانياً: مقياس أساليب المعاملة الوالدية اعداد الباحثة: الخصائص السيكومتربية للمقياس:

الاتسـاق الـداخلى للعبـارات: قامـت الباحثة بحسـاب الاتسـاق الداخلي وبحسـاب معـاملات

\begin{tabular}{|c|c|c|c|c|c|c|c|c|c|c|c|}
\hline \multicolumn{2}{|c|}{ المساواة } & \multicolumn{2}{|c|}{ الارشاد } & \multicolumn{2}{|c|}{ التقبل } & \multicolumn{2}{|c|}{ الحماية } & \multicolumn{2}{|c|}{ التساهل } & \multicolumn{2}{|c|}{ الرفض } \\
\hline الارتباط & 5 & معامل الارتباط & 5 & معامل & 5 & الارتباط & r & الارتباط & r & معامل الارتباط & r \\
\hline $.7 \wedge \varepsilon$ & 1 & $.0 Y \wedge$ & 1 & $* .791$ & 1 & $* * .0 \vee 99$ & 1 & $* *,, \uparrow, 7$ & 1 & $* . . \leqslant 97$ & 1 \\
\hline..$\leqslant 9 \wedge$ & $r$ &. $.7 \cdot V$ & r & $* . .7) \mathrm{V}$ & r & $* *,, 719$ & r & **..VI. & r & $* 0.9$ & r \\
\hline .019 & $r$ & 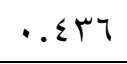 & r & $*$ *. $\leqslant 0 \%$ & r & $* * \cdot, T Y \Lambda$ & r & $* *, 701$ & $r$ & $*, 01 \leqslant$ & $r$ \\
\hline
\end{tabular}
الارتباط بين درجة كل عبارة والدرجة الكلية للبعد (ن=.ب) والنتائج كما يلي:

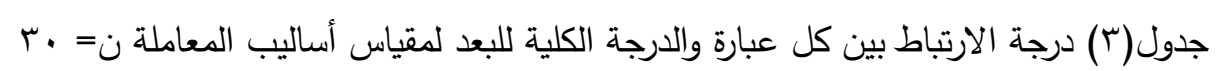

1673

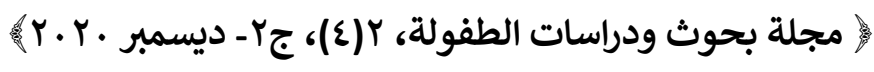




\section{كلية التربية للطفولة المبكرة- جامعة بني سويف}

\begin{tabular}{|c|c|c|c|c|c|c|c|c|c|c|c|}
\hline $.71 Y$ & $\varepsilon$ & $.0 \%$. & $\varepsilon$ & $* .000$ & $\varepsilon$ & $* *,, 0 \vee 9$ & $\varepsilon$ & ** . V . & $\varepsilon$ & $*, \quad \tau \leq r$ & $\varepsilon$ \\
\hline.$\vee 001$ & 0 & .770 & 0 & $* .070$ & 0 & $* *,, \nearrow Y \nearrow$ & 0 & $* * . .0 \leqslant Y$ & 0 & $*, \wedge \circ 0$ & 0 \\
\hline $.7 \wedge \varepsilon$ & 7 & . Tro & 7 & 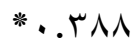 & 7 & $* *$, Or & 7 & $* *,, 770$ & 7 & $*, 0 \leq 9$ & 7 \\
\hline.$\vee V \backslash \varepsilon$ & V & $.7 T \wedge$ & V & $* .019$ & V & $* *, r q q$ & V & $* *,, 0 \wedge 1$ & V & $*, \wedge \leq \vee$ & V \\
\hline.$T A V$ & $\wedge$ & $.70 \leqslant$ & $\Lambda$ & $* .071$ & $\wedge$ & $* * .01 Y$ & $\wedge$ & $* * .071$ & $\Lambda$ & *., ו & $\Lambda$ \\
\hline .019 & 9 & .704 & 9 & $* .00 r$ & 9 & $* * .0 T r$ & 9 & $* * .077$ & 9 & $*, \wedge 07$ & 9 \\
\hline . & 1. &. .011 & 1 . & *. . . & 1 . & **. . . I & 1 . & $* * .0 \wedge r$ & 1 . & * , , & 1 . \\
\hline \multirow[t]{2}{*}{$.7 V \varepsilon$} & 11 & & & & & & & & & $* .0 \wedge 9$ & 11 \\
\hline & & & & & & & & & & $* .70 r$ & Ir \\
\hline
\end{tabular}

أشارت النتائج فى جدول(ץ) أن معاملات الارتباط لعبارات مقياس أساليب المعاملة الوالدية جميعها معاملات ارتباط دالة احصائياً عند مستوي ا...

الثبات: قامت الباحثة بحساب ثبات مقياس أساليب المعاملة الوالدية باستخدام الطرق التالية: (أ) معادلة ألفا كرونباخ: وذلك على عينـة بلغت(• • من المفحوصين، وذلك لأن المقياس على متدرج ثلاثي ومن ثم يصلح هذا النوع من أنواع معادلات حساب الثبات وكانت

$$
\text { النتائج كما هي ملخصة فى جدول(ع ) }
$$

(ب) طريقـة اعـادة التطبيق: قامت الباحثة بحساب ثبات اعادة التطبيق بتطبيق المقياس

بفاصل زمني أسبوعين ، والنتائج موضحة فى جدول(؟)

$$
\text { جدول( §) }
$$

\begin{tabular}{|c|c|c|}
\hline التجزئة النصفية & ألفا كرونباخ & الأبعاد \\
\hline$\cdot v \vee \Lambda$ & $\cdot \Delta Y_{1}$ & الرفض \\
\hline .V07 & $\because \vee \wedge \diamond$ & التساهل \\
\hline$\because \vee \wedge q$ & $\because v \leq 1$ & الحماية \\
\hline$\because V \leq 0$ & r. vor & التقبل \\
\hline$\cdot . \wedge 1 \leq$ & 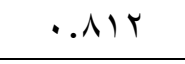 & الارشاد \\
\hline$\because \vee>0$ & $\because \vee \wedge q$ & المساواة \\
\hline
\end{tabular}

r r • بعاملات الثبات بطريقة ألفا والتجزئة النصفية ن

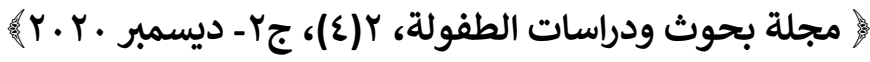




\section{الأساليب الإحصائية المستخدمة:}

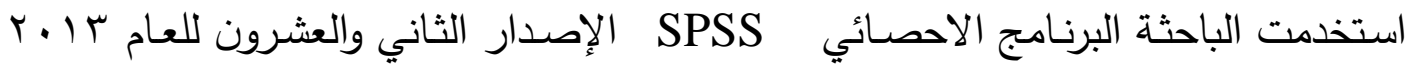
بهدف احتساب الاختبارات الإحصائية التالية: معامل الفا كرونباخ a-chronbach coefficient.

اختبار التاء للعينات المستقلة Independent samples T test والذي يتم احتساب تصني القيمة التائية T في حالة المتغير الثنائي ، وقد استخدمته الباحثة في المقارنة بين استجابات عينة الدراسة حسب متغير النوع (ذكر - أنثي) والأب والأم. معاملات الارتباط ت تحليل الاتحدار المتعدد. • المتوسطات والانحرافات المعيارية. نتائج الفرض الأول ومناقثتها: وينص على أنه توجد علاقة دالة احصائياً بين درجات الأطفال المعاقين بصريا علي مقياس

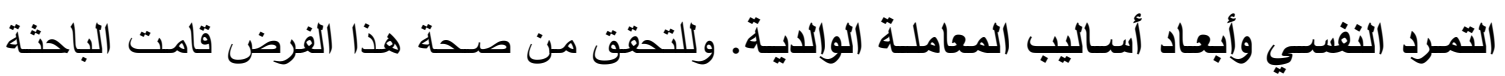
بحسـاب معامل ارتباط بيرسون ويعرض جدول(ه) معاملات الارتباط مقيساس التمـرد النفسـي

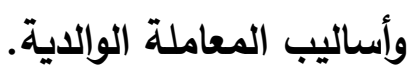

$$
\text { جدول (0) }
$$

معاملات الارتباط بين مقياس التمرد النفسي وأبعاد أساليب المعاملة الوالدية

\begin{tabular}{|c|c|c|c|c|c|c|}
\hline المساواة & الارشاد & التقبل & الحماية & التساهل & الرفض الرف & الأبعاد \\
\hline ..74.- & **..vor- & $* * . . v \cdot 0-$ & $* * . . \vee \cdot 0$ & $* * . . \vee 09$ & $* * . . \vee 7$. & الدرجة الكلية للتمرد \\
\hline
\end{tabular}

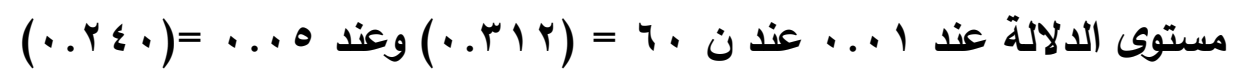


يتضح من الجدول السابق ما يلي:وجود علاقة بين أبعاد مقياس التمرد النفسي حيث كانت النتائج كما يلي:

- - توجد علاقة موجبة بين التمرد النفسي وأبعاد الرفض والتساهل والحماية ومن ثم فإن استخدام أساليب الرفض والتساهل والحماية يرتبط بارتفاع مستوي التمرد النفسي. وهو ما يشير الي أن استخدام الوالدين لأساليب الرفض والتساهل والحماية يرتبط بارتفاع مستويات التمرد النفسي لدي الأطفال المعاقين بصرياً. - - توجد علاقة سـالبة بين أسـاليب التقبـل والارشـاد والمسـاواة وبين التمـرد النغسي لدي الأطفال المعـاقين بصـريا وهو ما يشير إلى أن استخدام هذه الأسـاليب يقلل التمرد النفسي لدي الأطفال المعاقين بصرياً.

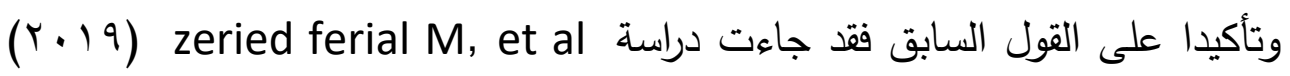
للتحقق من موقف الأبناء ذوى الإعاقة البصرية فى مرحلة الطفولة المتأخرة وتم فحص سلوك الوالدين وقد أثبت أن 57\% من الأبناء ينظرون إلى اساليب المعاملة السويها على انها تحقق دعم الثقة لديهم وان كل من هذه الأساليب لها الدور الفعال فى التأثير على شخصية ابنائهم ذوى الإعاقة البصربة كما جاءت دراسة فتيحة مقحوت (عا · ب) التى اكدت على أهمية استخدام أساليب المعاملة الوالدية السويـة وأن الوقوف على هذه الأساليب قد يساعد في تحقيق الصحة النفسية للأبناء والبعد كل البعد عن المشكلات السلوكية التي تتتاب الأطفال نتيجة لسوء معاملتهم. وقد أكدت ايضا دراسة الظاهرة محمود المغربي علي (9 ( ا ب) على أن وجود العلاقة الموجبة التي تقدم على أساليب المعاملة الوالدية السوية قد تؤدي إلى النجاح في تربية الأبناء والبعد كل البعد عن المشكلات السلوكية الغير سوية ومنها التمرد النغسي الذي يلحق بالعديد من الأبناء وخاصةةً في مرحلة المراهقة. 


\section{كلية التربية للطفولة المبكرة- جامعة بني سويف}

نتائج الفرض الثاني ومناقشتها: ينص هذا الفرض على أنه توجد فروق ذات دلالة إحصائية في فى مقياس التمرد النفسي والدرجة الكلية وفقاً للنوع (ذكور/اناث) وللتحقق من صحة هذا الفرض قامت الباحثة بحساب المتوسطات الحسابية والانحرافات المعيارية لدرجات الأطفال المعاقين بصرياً كما قامت باستخدام الاختبار الإحصائي اختبار ت للتحقق من دلالة الفروق بين المجموعتين وكانت النتائج كما هي موضحة بالجدول(؟): جدول) (†) المتوسطات والانحرافات المعيارية وقيمة (ت) ودلالتها للفروق فى أبعاد مقياس التمرد النفسي والدرجة الكلية وفقاً للنوع

\begin{tabular}{|c|c|c|c|c|c|c|}
\hline \multirow{2}{*}{ مستوى } & \multirow[t]{2}{*}{ قيمة ت } & \multicolumn{2}{|c|}{ اناث (ن=• ب) } & \multicolumn{2}{|c|}{ ذكور (ن=.r) } & \multirow{2}{*}{ 章 } \\
\hline & & $\varepsilon$ & s & $\varepsilon$ & 5 & \\
\hline$\cdots 1$ & $9.1 \cdot r$ & IT.AT & OV.VT & $1 \leq . Y 7$ & 9 q.1. & الدرجة الكلية للتمرد \\
\hline
\end{tabular}

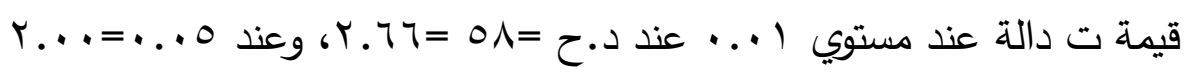

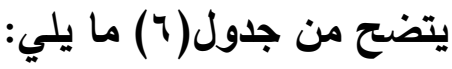

وجود فروق ذات دلالة احصائية بين متوسطات الذكور والاناث فى التمرد النفسي حيث كانت قيمة ت دالة وكانت الفروق لصالح المتوسطات الأعلي وهي الذكور وهو ما يعني أن الذكور أكثر تمردا بالمقارنة بالاناث .

فقد جاءت دراسة ندى فتاح زيدان ودراسة ميساء يحيى قاسم (V . . . ألتؤكد على نتائج الفرض السابق،حيث كان الهدف منها التعرف على الفروق فى المتوسطات الدرجات الخاصة بالتمرد النفسى يبين الجنسين واظهرت النتائج وجود فروق احصائية بين الجنسين فى التمرد النفسى لصالح الذكور حيث اكدت الدراسة على أن التمرد النفسى يحدث عند الذكور لأسباب ذاتية منها الغرور، وعدم تحمل المسئولية وضعف ثقة الطالب بنفسة والرغبة الزائدة فى جذب الانتباه واساليب المعاملة الوالدية الخاطئة . 


\section{كلية التربية للطفولة المبكرة- جامعة بني سويف}

نتائج الفرض الثالث ومناقشتها: ينص هذا الفرض على أنه توجد فروق ذات دلالة إحصائية في فى أبعاد مقياس أساليب المعاملة الوالدية وفقاً لمتغير النوع (أب/أم). وللتحقق من صحة هذا الفرض قامت الباحثة بحساب المتوسطات الحسابية والانحرافات المعيارية لتقرير الأباء لأساليب المعاملة الوالدية المستخدمة مع الذكور والاناث كما قامت باستخدام الاختبار الإحصائي اختبار ت للتحقق من دلالة الفروق بين الدجوعتين وكانت النتائج كما هي موضحة بالجدول(V): - (V)

جدول (V) المتوسطات والانحرافات المعيارية وقيمة (ت) ودلالتها للفروق فى أبعاد مقياس

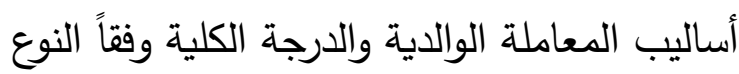

\begin{tabular}{|c|c|c|c|c|c|c|}
\hline \multirow{2}{*}{ الدلالة } & \multirow[t]{2}{*}{ قيمة ت } & \multicolumn{2}{|c|}{ 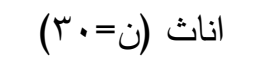 } & \multicolumn{2}{|c|}{ ذكور (ن=.r) } & \multirow{2}{*}{ 诵 } \\
\hline & & $\varepsilon$ & s & $\varepsilon$ & s & \\
\hline$\cdots 1$ & $11.19 \mathrm{~V}$ & V.Or & $1 \leq .9$. & r.11 & $\varepsilon \cdot .9 r$ & الرفض \\
\hline$\cdots 1$ & $10.1 \leqslant r$ & $0 . .7$ & Tr.r & r.rq & gr.r. & التساهل \\
\hline$\cdots 1$ & 11.7111 & T. $Y \leq$ & IV.rT & r.ov & r..VT & الحماية \\
\hline$\cdots 1$ & $\mid r . \wedge \leq 0-$ & 7.77 & سTr.VT & $\varepsilon .17$ & $1 T . \wedge 7$ & التقبل \\
\hline$\cdots+1$ & YT.VYT- & $r .01$ & .r.r. & r.10 & س & الارشاد \\
\hline$\ldots 1$ & $1 T . V \leq 7-$ & T.17 & M.l. & $\varepsilon \ldots 1$ & $1 \wedge .11$ & المساواة \\
\hline
\end{tabular}

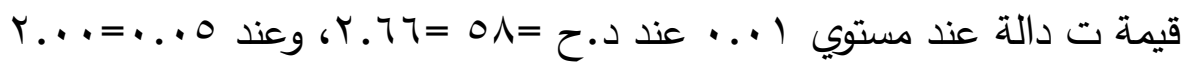

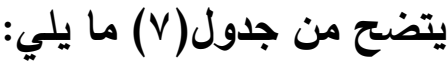

وجود فروق ذات دلالة احصائية بين متوسطات مجموعتي الذكور والاناث فى جميع أبعاد مقياس أساليب المعاملة الوالدية حيث كانت قيمة ت دالة للأبعاد والدرجة الكلية وكانت الفروق لصالح الكتوسطات الأعلي وهي لصالح الذكور في أبعاد الرفض والتساهل والحماية بينما كانت الفروق فى أبعاد التقبل والارشاد والمساواة لصالح الاناث. 


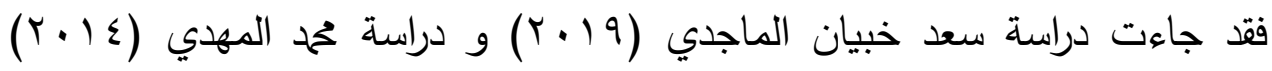

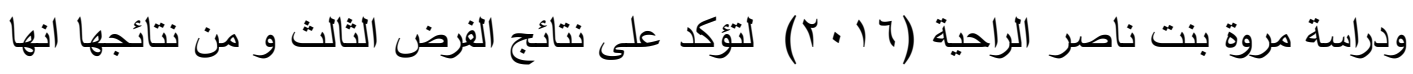

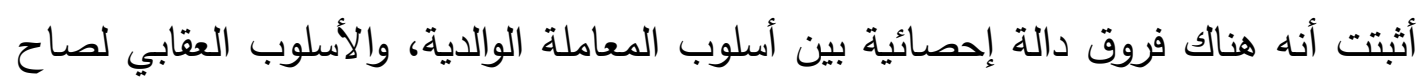

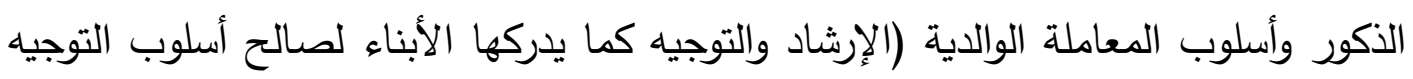

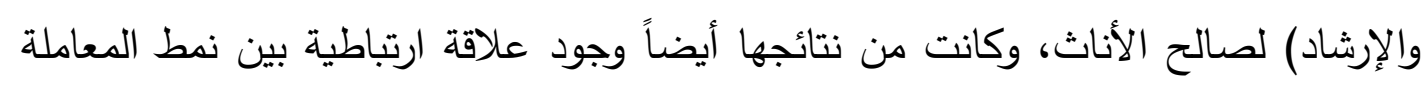
الوالدية وسلوك الأبناء. نتائج الفرض الرابع ومناقشتها: الفرض الرابع: ينص الفرض على أنه يمكن التتبؤ بالتمرد النفسي من خلال أبعاد أساليب المعاملـة الوالديـة : وللتحقق من صحة هذا الفرض، قامت الباحثة باستخدام تحليل الانحدار المتعدد لقياس مدى امكانية التتبؤ بالتمرد النفسي من خلال أبعاد المعاملة الوالدية. وقد قامت الباحثة أولاً بالاطمئنسان على تحقق الافتراضـات الأساسية لاستخدام تحليل

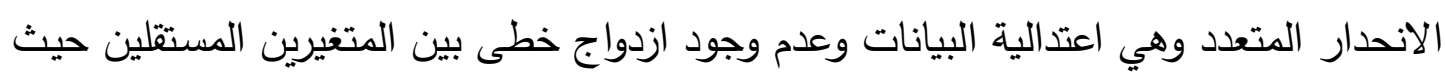

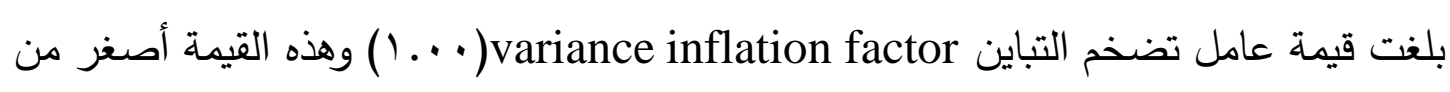

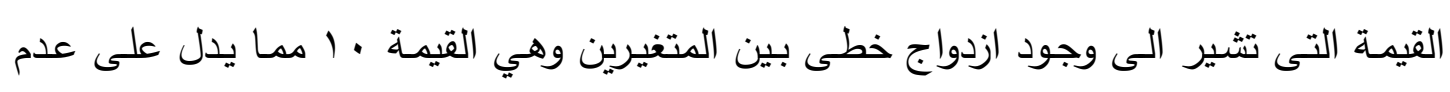

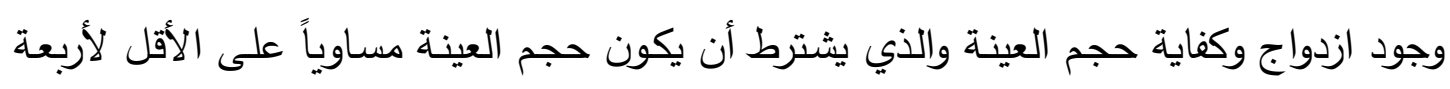

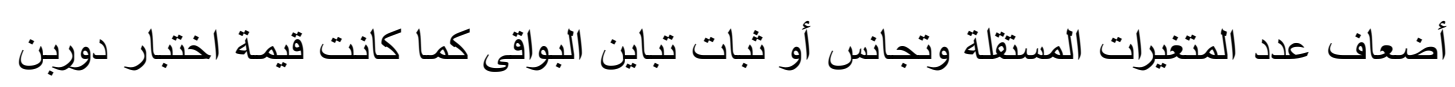

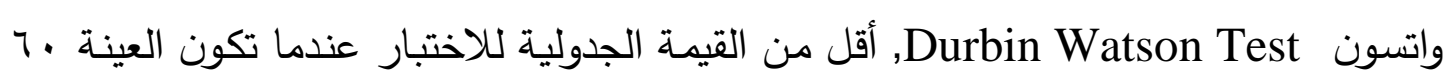
وعدد المتغيرات المستقلة

باستخدام اختبار تقدير دالة الانحدار وجد أن أنسب نموذج للعلاقة بين التمرد النفسي

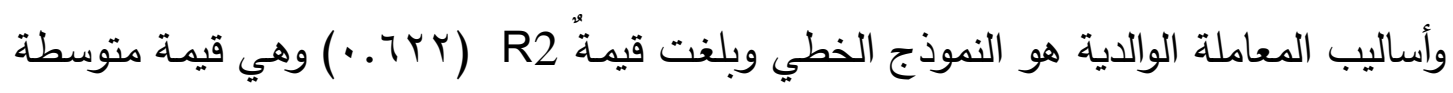

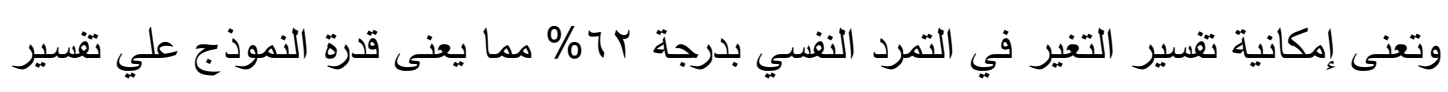
1679

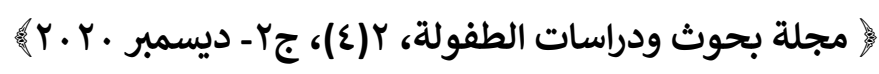




\section{كلية التربية للطفولة المبكرة- جامعة بني سويف}

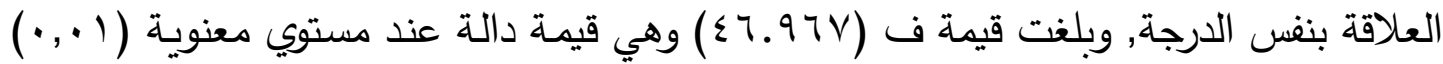
وبلغت قيمة الثابت 9ץ . .ع وهي دالة احصائياً.

$$
\text { جدول(^) }
$$

تحليل الانحدار المتعدد للمتغيرات النفسية في التتبؤ بالتمرد النفسي

\begin{tabular}{|c|c|c|c|c|c|c|c|c|}
\hline الإحصائية & قيمة & الانحدار & 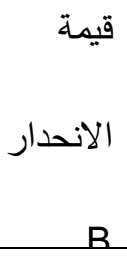 & المستغير & قيمة ف & معامل & $\begin{array}{r}\text { الارتباط } \\
\text { R }\end{array}$ & \\
\hline$\ldots 0$ & $T . T \leqslant 0$ &.$\leqslant 10$ & 9 & الرفض & $\leqslant 7.97 \mathrm{~V}$ & . .TYY & $\therefore \vee \wedge १$ & التمرد \\
\hline$\ldots 0$ & T.OVA & .. $\varepsilon \varepsilon$ & .941 & التساهل & & & & \\
\hline
\end{tabular}

وتثير النتائج فى جدول (^) أبعاد الرفض والتساهل كانت أقوي المنبئات بالتمرد النفسي بينما استبعدت معادلة الانحدار المتعدد باقي الأبعاد حيث لم تكن منبأة وفيما يلي معادلة الانحدار :

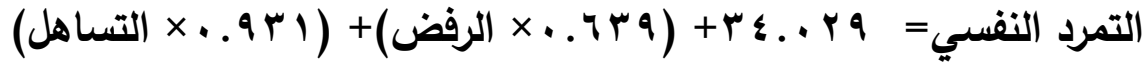
نتائج الفرض الخامس: ينص الفرض الخامس علي: يرتقع مستوي الرفض باعتباره أكثر أساليب المعاملة الوالدية استخداما مع الأطفال المعاقين بصرياً وللاجابة علي هذا السؤال استخدمت الباحثة اختبار ت للمجموعة الواحدة للتعرف علي دلالة الفرق بين المتوسط الفعلي لدرجات أساليب المعاملة الوالدية والمتوسط الفرضي الذي يتحدد بنصف الدرجة علي المقياس وجاءت النتائج كما هي مبينه فى جدول(9) 
كلية التربية للطفولة المبكرة- جامعة بني سويف

\begin{tabular}{|c|c|c|c|c|c|c|}
\hline المستوي & الدلالة & قيمة ت & الالانحراف & الفتعلي & الفرضي & الأبعاد \\
\hline أعلي من & $\cdots 1$ & T.MrI & $1 \leq . r T$ & YV.q1 & rr & الرفض \\
\hline أعلي من & $\ldots 0$ & r.rol & 9.01 & $Y \leq . V T$ & $r$. & التساهل \\
\hline أعلي من & $\ldots 0$ & r.0.r & $\vee . \wedge \varepsilon$ & r $\{.0 r$ & $r$. & الحماية \\
\hline غير دال & د.غ & I.r. & $11 . \varepsilon r$ & rr.A. & $r$. & التقبل \\
\hline غير دال & د.غ & 1.107 & $9 . \leqslant 7$ & TE.YT & $r$. & الارشاد \\
\hline أعلي من & $\cdots 1$ & r.VIr & $V . \leqslant V$ & $r \varepsilon .7)$ & Yr & المساواة \\
\hline
\end{tabular}

يتضـح من الجدول أن أكثر أسـاليب المعاملـة الوالديـة استخداما مـع الأطفال المعاقين بصريا هو أسلوب الرفض حيث كان أعلي الأساليب بمقارنة المتوسط الفرضي بالمتوسط الفعلي وكانت قيمة ت دالة احصائياً.

وقد جاءت العديد من الدراسات التى تدعم نتائج الفرض الثالث حيث جاءت

دراسة أمل السعيد عبد الحليم (11 ( ب) ودراسة مروة بنت ناصر الراجحية واسماء بنت سعود الحتمية (T ( ب ( ) حيث اكدوا على أن ارتفاع مستويات انماط المعاملة الوالدية المستخدمة مع ابنائهم ذوى الإعاقة البصرية هم اساليب الرفض والسلطة والأساليب الحازمة وانخفاض اساليب المعاملة الوالدية الخاصة بالتساهل والفبول ، وفنجد ايضا

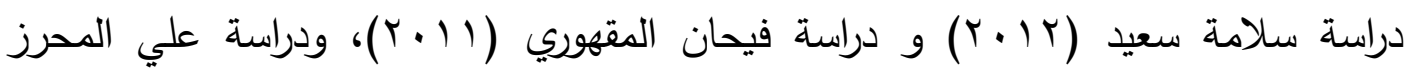

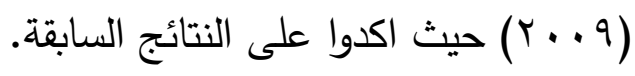




\section{التوصيات}

1-العمل على توعية الوالدين بضرورة إعطاء فرصة لأبنائهم لكى يعبروا عن أنفسهم ومشاركتهم فى ابداء رأيهم ، وغرس الثقة فى انفسهم •

ץ- إن من اكثر الأساليب التى تساعد على إنماء اسلوب التمرد هو العقاب البدنى واللفظى مما يؤدى إلى فقد الثقة والثعور بالأحباط الثديد لاى الأبناء فلابد من

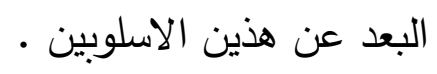

r- مساعدة الأبناء فى حل مشكلاتهم وتوفير المرشدسن والأخصائئين النفسيين وإعداد البرامج الإرشادية التى تحد من ظاهرة التمرد النفسى • ع - اقامة الندوات والملتقيات الخاصة باساليب المعاملة الولدية السوية المبنية على الحوار والإرشاد والتوجية وابراز مدى اهميتها فى حياة الأبناء المتمردين نفسيا ومدى تأثيرها على شخصياتهم فى حياتهم المستقبلية . ه- ضرورة اهتمام المدرسة بالجوانب الإنفعالية والإجتماعية للطلبة وعدم الأقتصار على الجانب المعرفى التحصيلى . البحوث المقترحة

ا- إجراء المزيد من الأبحاث المماثلة لهذا البحث على عينات اخرى من فئات · المجتمع

r- اثر سوء المعاملة الوالدية على التوافق الأجتماعى والنمو الخلقى لدى ضعاف السمع فى مرحلة الطفولة المتأخرة . 
r- فعالية برنامج ارشادى لتدريب الوالدين على التعامل بإيجابية مع ابنائهم المعاقين

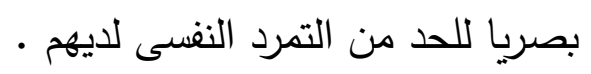

ع - فعالية برنامج ارشادى علاجى لتخفيف التمرد النفسى الذى يعانيه ذوى الإعاقة

البصرية فى مرحلة الطفولة المتأخرة .

\section{قائمة المراجع}

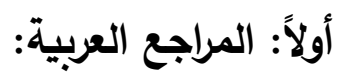

ابتسام العبدي علي اللامي (1 . ب). أساليب المعاملة الوالدية وعلاقتها بالتمرد النفسي لدى الثباب. رسالة ماجستير غير منشورة. كلية الآداب المستصرية. العراق. أحمد هاشمي (ع . . ب). الأسرة والطفولة. دار قرطبة. ط الأولى.

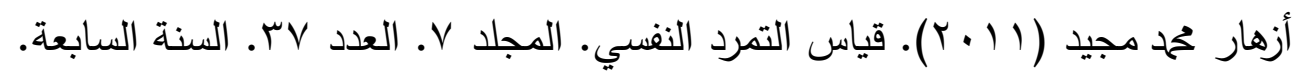
إقبال محم رشيد الحمداني (9... ب). الاغتراب وعلاقته بالتمرد وقلق المستقبل لدى طلبة الجامعة. رسالة دكتوراه. كلية التربية. جامعة بغداد. العراق.

أمال السعيد عبد الحليم (1) ب (1). أساليب المعاملة الوالدية كما يدركها الطفل الكفيف وعلاقتها ببعض المتغيرات النفسية. رسالة ماجستير . قسم العلوم التربوية والنفسية. كلية التربية. جامعة بنها. آمنة عويد شدهان، داليا كاظم فرهود، منتصر إسماعيل (Y V. Y). التمرد النفسي لدى طلبة كلية التربية. بحث مقدم من متطلبات شهادة البكالوريوس في علم النفس. كلية التربية.

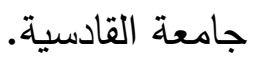
إيهاب عبد العزيز الببلاوي (ع (ب). توعية المجتمع بالإعاقة. الفئات- الأسباب- الوقاية.

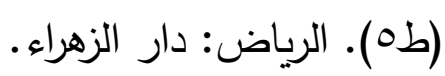




\section{كلية التربية للطفولة المبكرة- جامعة بني سويف}

بطرس حافظ بطرس (^ ...r). التكيف والصحة النفسية. دار المسيرة للنشر والتوزيع

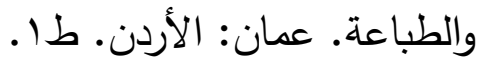

بطرس حافظ بطرس (• ( • ب). تكيف المناهج للطلبة ذوي الاحتياجات الخاصة. الأردن: دار

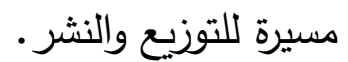

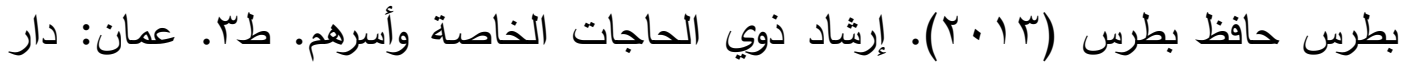

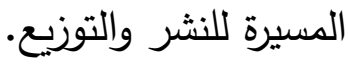

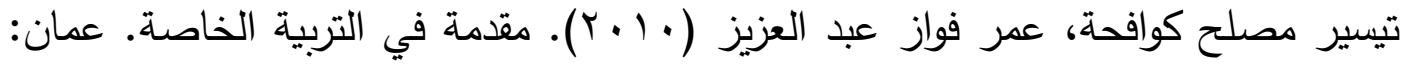
دار المسيرة للنشر والتوزيع. ط الرابعة.

جمال محم الخطيب، منى محمد صبحي الحديدي (9 . . ץ). مطبعة دار الفكر، الطبعة الأولى. جمال مختار حمزة (0. . ب). بعض أساليب المعاملة الوالدية كما يدركها الأبناء وعلاقتها بالأمن النفسي لذاتهم. مجلة علوم التربوية. العدد الثالث. جامعة القاهرة.

حامد عبد السلام زهران (9 (1 ) ). الصحة النفسية والعلاج النفسي. القاهرة: عالم الكتب. خلود بثير عبد الواحد (0 . . ץ). أثر برنامج تربوي لتخفيف التمرد النفسي لدى المراهقين. رسالة ماجستير . كلية التربية. جامعة الموصل. العراق. خولة ححمد زايد مطارنة (990 (19). العلاقة بين الضغوط النفسية و التمرد لدى المراهقين. رسالة ماجستير غير منشورة. كلية العلوم التربوية. جامعة مؤتة الأردن.

زينب حسن فيح الجبوري، مؤيد عبد الرازق حسو (Y V) (Y). التمرد النفسي والتفكير اللاعقلاني وعلاقتهما بسلوك العنف لدى طلبة كلية التربية البدنية وعلوم الرياضة. مجلة

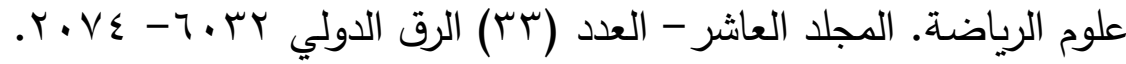
زينب شقير (999 (1). سيكولوجية الفئات الخاصة والمعوقين. القاهرة: مكتبة النهضة

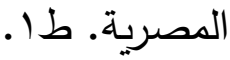




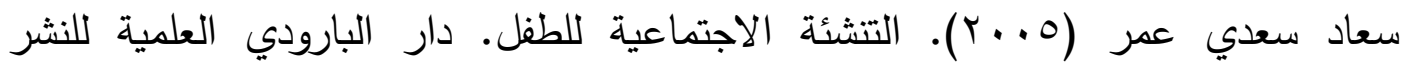
والتوزيع. عمان: الأردن.

سعد حنبيان الماحدي (9 ( ب ). أساليب المعاملة الوالدية وعلاقتها بالسلوك العدواني لاى الأبناء من طلبة المرحلة الثانوية. ماجستير الإرشاد النفسي المدرسي. جامعة الكويت. سعدية بهادر ( (99 1). علم نفس نمو الطفولة والمراهقة. عمان: دار المسيرة للنشر والتوزيع الطباعة.

سكينة جميل الوحيدي (ج . . ץ). العلاقة بين تواصل الأسرة الأردنية ومرونتها وتماسكها من جهة وتمرد المراهقة فيها من جهة أخرى. رسالة ماجستير . كلية الدراسات العليا. جامعة عمان المصرية. الأردن.

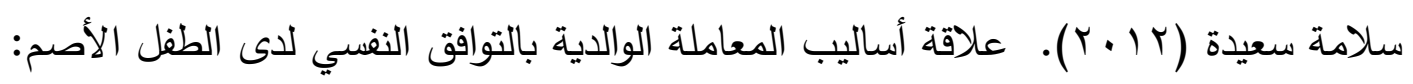
دراسة ميدانية بمدرسة ابن سينا لصغار الصم بالبوبرة. رسالة ماجستير غير منشورة. جامعة العقيد أكلي محسند أو الحاج: الجزائر. صالح حسن الدهري (^ . . r). علم النفس. دار صفاء للنشر والتوزيع. صالح حسن الداهري (0. . †). علم النفس الإششادي نظرياته وأساليبه الحديثة. دار وائل للطباعة والنشر والتوزيع.

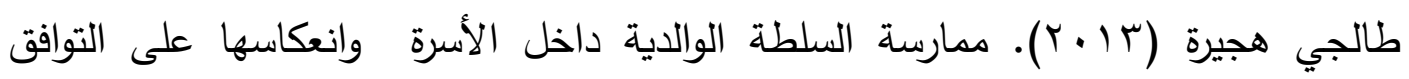
النفسي الاجتماعي للمراهق. رسالة ماجستير غير منشورة. جامعة وهران, الجزائر. الظاهرة محمود المغربي (9 ( • ( ). تتبؤ الأساليب الوالدية المدركة في مرحلة الطفولة بالذكاء الوجداني كقدرة في مرحلة المراهق المتأخرة. دراسات نفسية دورية علمية. المجلد التاسع والعشرون. العدد الثاني. أبريل 9 أ. أ. 


\section{كلية التربية للطفولة المبكرة- جامعة بني سويف}

عبد العزيز خواجة (0. ب). مبادئ في التتشئة الاجتماعية. دار الغزيب للنشر والتوزيع،

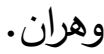

عبد الله عويدات (99v1). أثر أنماط التنشئة الأسرية على طبيعة الانحرافات السلوكية عند طلبة الصفوف الثامن والتاسع والعاشر / الذكور في الأردن. دراسات (العلوم التربوية). $.1 .1-\lambda r_{6}(1) r \varepsilon$

عبد المحسن عبد المقصود سلطان (0. . r). دور المجتمع نحو أبنائه من ذوي الاحتياجات الخاصة. دار العلم والثقافة. طا.

عبد المطلب القريطي (1999). سيكولوجية ذوي الاحتياجات الخاصة وتربيتهم. القاهرة: دار

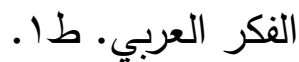

عبد المطلب أمين القريطي (1991). سيكولوجية ذوي الاحتياجات الخاصة وتربيتهم. القاهرة: مكتبة دار الفكر العربي.

عبد ربه شعبان (· ( ( ). الخجل وعلاقته بتقدير الذات ومستوى الطموح لدى المعاقين بصرياً. رسالة ماجستير ـ كلية التربية. قسم علم النفس، الجامعة الإسلامية. غزة.

علاء الدين كفافي (9. . ب). علم النفس الأسري. طץ. القاهرة: دار الفكر . علي آل محرز (9. . ب). الاتجاهات الوالدية في التنتئة كما يدركها الطلاب الصم بالمرحلة المتوسطة والثانوية بالعاصمة الsقدسة وعلاقتها بمفهوم الذات. رسالة ماجنتير غير منشورة. جامعة أم القرى: المملكة العربية السعودية. علي حسين الحلو (r...r). الانحرافات السلوكية للشباب وسبل مواجتها. مؤتمر وقائع المؤتمر العبي العلمي الأول. المجلد (1). جامعة بغداد. وزارة التعليم العالي والبحث العلمي. 
على محسن ياس ، محمود كاظم محمود (T ( + ).التمرد النفسى والتفكير المزدوج وعلاقتهما بالعنف الأرشاد النفسى والتوجية التربوى .الجامعة المستصرية. كلية التربية

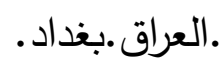

فؤاد عيد الجوالدة (r ( ب). الإعاقة البصرية. عمان: دار الثقافة للنشر والتوزيع. فاطمة المنتصر الكتاني ( . . . . الاتجاهات الوالدية في التنشئة وعلاقاتها بمخاوف الذات عند الطفل. دار المعرفة. الرباط. فاطمة مبارك ححم الحميدي (ع . . ب). دراسة السلوك العدواني وعلاقته بأساليب المعاملة الوالدية لدى عينة من طلاب المرحلة الإعدادية بدولة قطر. مجلة مركز البحوث التربوية. جامعية قطر • السنة الثالثة عشر . العدد الخامس والعشرون. فايز حضر بشير (r ( ب). التمرد وعلاقته بأساليب المعاملة الوالدية لدى طلبة جامعية الأزهر بغزة. رسالة ماجستير . كلية التربية. جامعة الأزهر . فلسطين. فايزة يوسف عبد المجيد (r ( • Y). المعاملة الوالدية كما يدركها الأبناء من الجنسيين وعلاقتها بالكفاءة الذاتية فى المرحلة العمرية (س ا-0 ()). مجلة دراسات الطفولة ـ مجلد 10 ـالعدد • اكتوبر ov

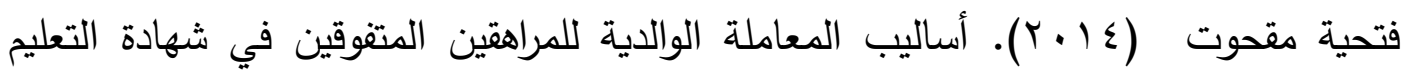
المتوسط. دراسة ميدانية بثانوية القبة الجديدة للرياضيات. الجزائر : العاصمة. رسالة ماجستير فضيلة عرفان السبعاوي (• ( • ). الخجل الاجتماعي وعلاقته بأساليب المعاملة الوالدية. دار صفاء للنشر والتوزيع. الطبعة الأولى. عمان. 


\section{كلية التربية للطفولة المبكرة- جامعة بني سويف}

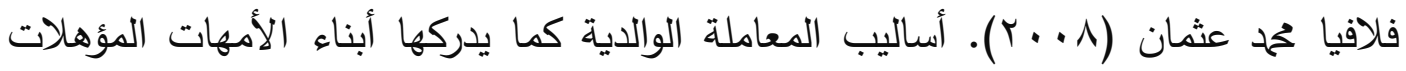
المتخصصات في مجال علم النفس والطفولة. رسالة ماجستير • معهد الدراسات العليا للطفولة. جامعية عين شمس. فيحان المقهوي (11 (1). أساليب المعاملة الوالدية كما يدركها الأبناء المكفوفين وعلاقتها بتقدير الذات لديهم. رسالة ماجستير غير منشورة. جامعية الإمام تحمد بن سعود الإسلامية. المملكة العربية السعودية.

فيصر ححم الزاد ( . . . ץ). قراءة في علم الثباب. مشاكل المراهقة والثباب. منتدى الكتاب. قحطان أحمد قحطان (ع . . ץ). تعديل السلوك. دار وائل للنشر والتوزيع. كمال سيسالم (ץ. . r). موسوعة التربية الخاصة والتأهيل النفسي. العين: دار الكتاب الجامعي.

مايسة أحمد النيال (ץ . . ץ). التششئة الاجتماعية. دار المعرفة الجامعية للنشر. الأزريطة. مصر

مجد خطاب (· ( (Y). علاقة أساليب التنشئة الوالدية بالخجل لدى أطفال الروضة في الأردن. رسالة ماجستير غير منشورة. جامعة عمان العربية. الأردن.

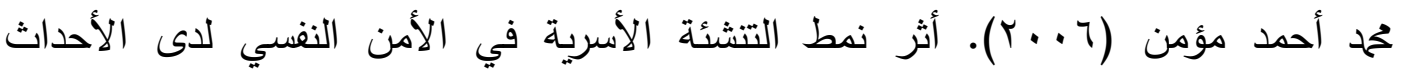

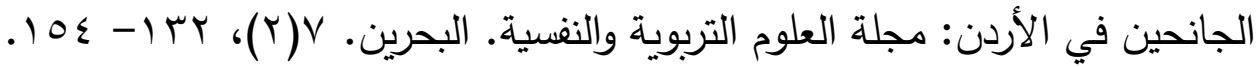
محمد الراجي (11 +r). المعاملة الوالدية والفشل الدراسي وعلاقة كل واحد منهم بالسلوك العدواني لدى تلاميذ المستوين الخامس والسادس من التعليم الأساسي. رسالة ماجستير غير منشورة. المركز الاستشاري البربطاني. المغرب. 
محم السعيد ابة حلاوة ( • • ( ). جودة الحياه المفهوم والأبعاد ـ المؤتمر العلمى السابع • كلية التربية. جامعة كفر الثيخ •جودة الحياة كاستمرار للعلوم التربوية والنفسية ـ الفترة من

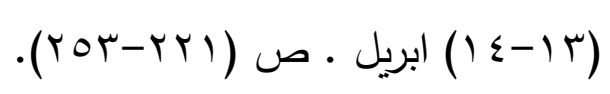

محمد المهدي عمر حمح (ع ( • r). المشكلات السلوكية وعلاقتها بأساليب المعاملة الوالدية لدى الطلاب ذوي الإعاقة البصرية في ضوء بعض المتغيرات الأسرية بمنطقة القصيم بالمملكة العربية السعودية. مجلة التربية الخاصة والتأهيل. المجلد (ץ) العدد (؟).

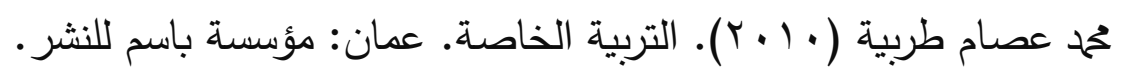

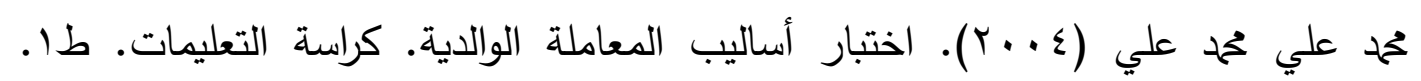
القاهرة: مكتبة النهضة المصرية.

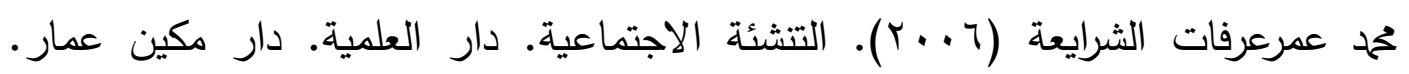

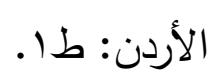

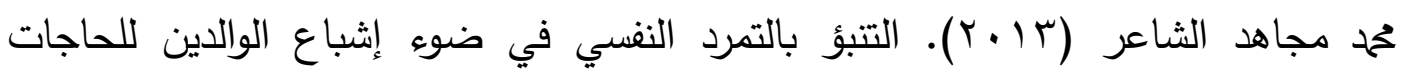
النفسية لدى عينة من المراهقين بمحافظة خان يونس. رسالة ماجستير . كلية التربية. جامعة الأقصى. غزة: فلسطين. مروة بنت ناصر الراجحية، أسماء بنت سعود الحاتمية (7 ( ب). أنماط التتشئة الوالدية كما يدركها المراهقون من المبصرين ومن ذوي الإعاقة البصرية في سلطة عمان. جامعة السلطان قابوس. سلطنة عمان: الملتقى السابع عشر للجمعية الخليجية للإعاقة

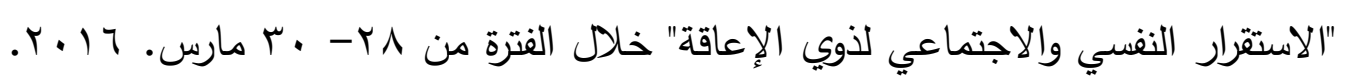
مدينة الكويت. منى ححم صبحي الحديدي (ع . . ب). مقدمة في الإعاقة البصرية. دار الفكر . عمان: الأردن.

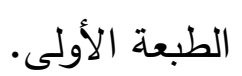




\section{كلية التربية للطفولة المبكرة- جامعة بني سويف}

نجلاء إبراهيم صديق (•(ب). الضغوط النفسية لاى المراهين المعاقين بصرياً بمعه النور للمكفوفين ببصرى وعلاقتها ببعض المشكلات السلوكية. رسالة ماجستير. كلية الآداب.

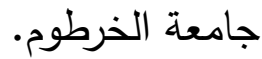

نزية الجندي (•(ب). التتشئة السوية للأبناء كما يدركها الوالدان. مجلة جامعة دمشق.

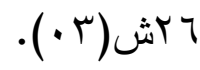

نصر الدين جابر (.... r). العوامل المؤثرة في طبيعة التتشئة الأسرية للأبناء. مجلة جامعية دمشق للآداب والعلوم الإنسانية والتربوية. مجلد 17 ـ العدد ؟ّ.

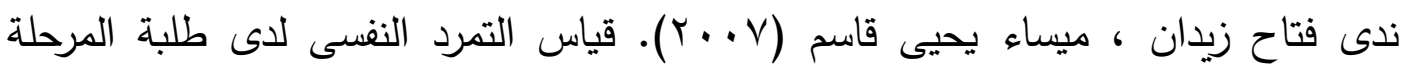
الأعدادية ـ مجلة التربية والعلم ـ مجلد ـا ا. العدد ؟r.

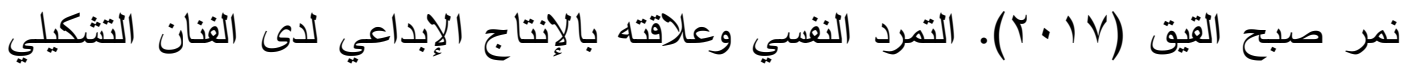

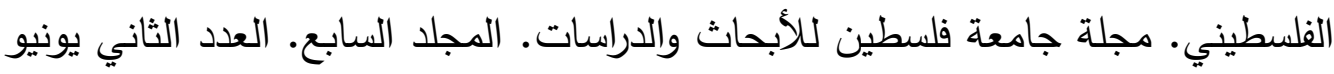
.$T \cdot I V$

نيفين زهران، سوسن المؤمن، وهيفا الدوسري (r (ب). القيم الأخلاقية وعلاقتها بأساليب التتنئة الوالدية لدى المراهقات بمدينة الرياض. مجلة عالم التربية. مصر. ـ ا ل (Tء)

$$
\text { (Iro-r) }
$$

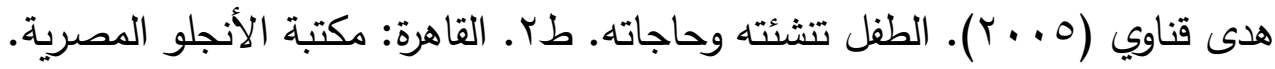
هول. ك ولينزي، ج (7/91). التعلم بالملاحظة- باندورا في غازادا- حي دكسوريستينظريات التعليم- دراسة مقارنة. ترجمة عطية محمود. عالم المعرفة. الكويت: المجلس الوطني للثقافة والفنون والآداب.

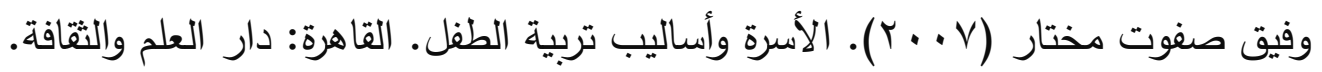




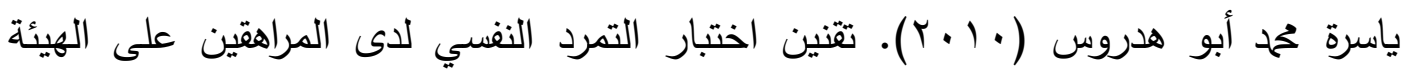

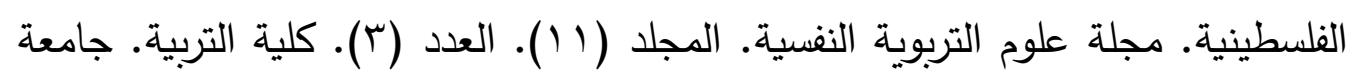

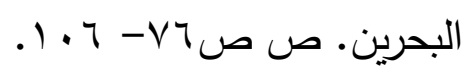

يوسف القريوطي ، عبد العزيز السرطاوى ، جميل الصمادى (1 . ب). المدخل إلى التربية

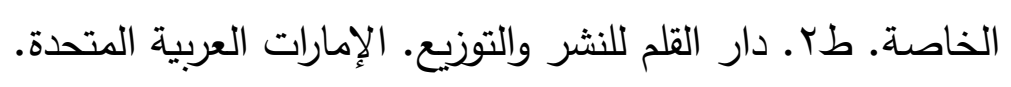

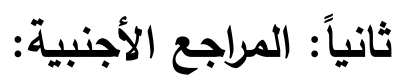

Bischoff. M. (1997). Predicrions of Client Resistance in the Counseling Interaction. Unpublished doctoral dissertation. University of Illinois. Urbana- Champaign.

Brehm, S.S. \& Brenm, J. W. (1981). Psychological Reactance A Theory of Freedom and Control. New York: Academic Press. P.93.

Buboltz, Jr \& Walter. C., (2001). The Hong Psychological Reactance Scale: A Confirmatory Factor Analysis. Measurement \& Evaluation in Counseling \& Development. (High Beam).

Chales Gardou (2010). Le handicap au Risqué des Cultures, Edition Fres France.

Chan, T, \& Koo, A. (2011). Parenting Style and Youth out Come in the UK. European Soliological Review. 27(3) 385- 399. Obi. 10. 1093/esr/jcqo.

Charles Gardou (2012). Parents D'enfants Handicapes Edition Fres, Lion. France.

Donnell, A., Tomas A., Bubolt Z, J. \& Wapter, C. (2001). Psychological Reactance: Facture Structure. Internal Consistency of the Questionnaire for the Measurement of Psychological Reaction, Journal of Social Psychology. 141 (5). 679- 687. 
Donnell, A., Tomas A., Bubolt Z, T. \& Wapter, C. (2001). Psychological Reactonce: Facture Structure \& Internat Consisteny of Questionnaire for the Measurement of Psychological Reactane. Journal of Social Psychology. 141 (5). 679- 687.

Ellen G. C. (2016). Asystematic, Reviw of the Lterature on Parenting of Young Children with Visual impairments and the Adaption Jor Video feed Sack inter Vent in to Promote Positive Parenting. Van Eijden. And Carlo Schuenzel. Journal of Development al and Physical Disabilities.

Hellman, C. \& MeMillin, W. (1997). The Relationship Between Psychological Reactance and Self-Esteem. Journal of Social Psychology. 137(1). 135- 138.

http://dspace.up.edu.ps/jspui/bitstream.pdf.2017.

Johnson, P., Bubolts, J. \& Walter, C. (2000). Differentiation of Self and Psychological Reactace. Contemporary Family therapy. An International Journal. 22 (1). 91.

Johnson, P., Bubolts. J. \& Walter, C. (2000). Differentiation of Self and Psychological Reactance. Contemporary Family Therapy. An International Journal. 22 (1). 91.

Joubert. E. (1995). Relationship Among Self-Esteem. Psychological Reactance, and other Personality Variables. Psychological Reports. (66). 1147- 1151.

Mario, A., Cooksto, T. (2007). Violent Victimization Agression \& Parent- Adolescent relation: Qualite Printing as Buffer for Violenty Victim Aires Youth. Journal of Youth \& Adolescence. 36 (5). 635647.

Metzke, Cw and Steinhousn, Ch (1999). The Importance of Parental Child- Rearing Behavior. School Environment and Social Network. Zeit Schrift fur Klinische Psychologie Forchung Undprayis. Vol. 28, No.2. 
Wrights man , L.S. (1972). Social Psychology. In the 7, Book Cole Publishing Company Monterey. Califoronia.

Zeried Ferial M, Seedq Abeer and Osuagwa Uchechukwu , (2019) . Influence of Parenting style on The visually impraied and their selfEsteem - Analysis based on A Saudi population. Department of Optometry and Vision Science.collage of Applied Medical sciences .Saudia Arabia. 


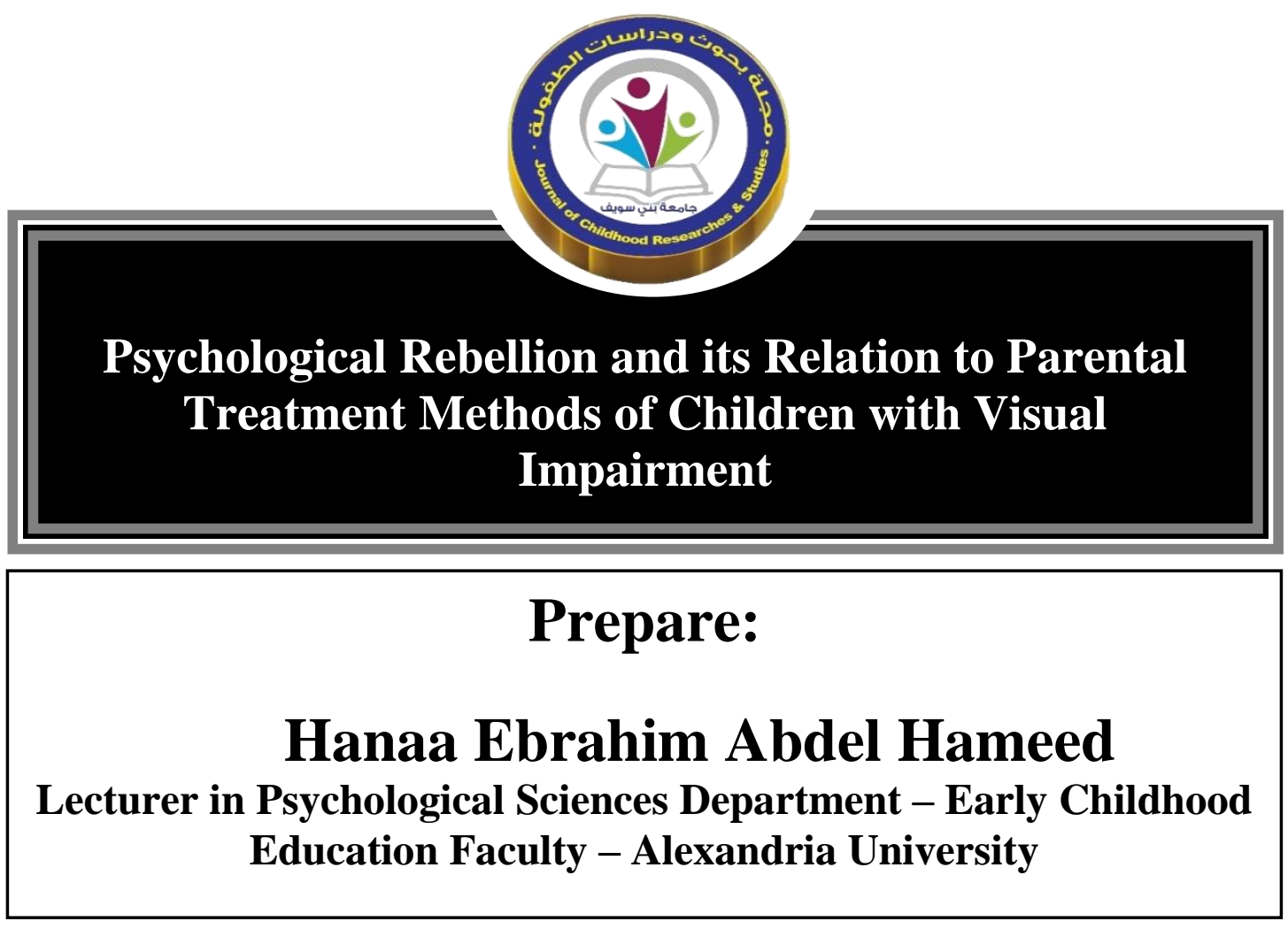

